상징과모래놀이치료, 제 11 권 제 1 호

Journal of Symbols \& Sandplay Therapy

2020, 6, Vol. 11, No. 1, 191-212.

doi https://doi.org/10.12964/jsst.20005

\title{
Symbolism of Snakes that Stimulate Restoration and Transformation of Visceral Vitality \\ Kim, Nam Kyoung
}

\begin{abstract}
$<$ Abstract $>$
Snakes are animals that often appear in religion, mythology, and fairytales. In these stories they have both sacred and destructive qualities. Snakes also appear as powerful emotions in individual dreams and sandplay cases. These snakes appear when consciousness is quite separated from instinct and provide an individual with a crucial opportunity for development and regression. Therefore, this study amplified various symbols of snakes and examined their meanings.
\end{abstract}

Keywords : snake, sacred and destructive qualities, powerful emotion

\footnotetext{
* Seongnam Children's Development Education Support Center, Counselor (godotess10@Daum.net)
} 
Journal of Symbols \& Sandplay Therapy, Vol.11 No.1.

\section{I . INTRODUCTION}

The end of Renaissance was marked with the decline of geocentricism, which was perceived as the psyche of God. The human psyche was then born, which led to the development of human consciousness (Jung, 2002). With modernization, human beings placed importance only on the unilateralism and rationality of consciousness and ignored the unconscious, in which consciousness originates. They started to view the unconscious as a mere byproduct of consciousness, and even came to associate instinct and drive with vulgarity. From the outside, the modern human being enjoys the convenience that comes from science and technology, but the mind is drifting away from its origin, and the vitality and meaning of life is fading away.

Animals are the foundation of religion, as they were considered and worshipped as images of God by the ancient and primitive people. They performed rituals for the animals before they went out to hunt, and if something went wrong, they did not go hunting that day (Von Franz, 1980). This religious consideration for animals reflects an attention to the divine power of the inner instinctive aspect. With the development of civilization, the image of God transformed from animals to animal-people gods, and then to human beings. This "reflects the development of consciousness that came with the development of awareness about the behavioral characteristics of the human being" (von Franz, 1999). This type of transformation in a civilization and religion is phylogenetically uniform within a single species. The journey of the mind towards consciousness may thus be another experience of world evolution, similar to the process of human evolution (Turner, 2009).

Animals are driven by purpose, and utterly abide by the rules of the collective unconscious. Thus, they may not only be the instinctive and impulsive beings that are below humans, but also those that possess the kind of divinity that surpasses humanness. The collective unconscious is made up of the archetype and instinct, and this life phenomenon is closely knit and inseparable (Rhi, 2005). In that sense, instinct, which is part of the unconscious psyche, holds many things that we cannot all know. It links us to the things of the origin that consciousness has left out, and becomes the impetus for vitality in the human life. 
Carl Gustav Jung said that "the system of symbolism in which animals appear is always an indication of a psychic process that starts at the animal level, or the instinct" (Jung, 1989), and that "from early on, animals in the unconscious symbolized an area of the human psyche hidden within the darkness of bodily drives" (Jung, 2002). Here, the animals play a substantial role in the psychic process. Among the animals that appear in most myths, legends and folktales, the serpent holds a special position. The researcher was pleasantly shocked to learn about the paradoxical image of the serpent in the Bible. While portraying the destructive and devilish characteristics of the serpent that led human beings to fall into sin, it also drew a parallel between the serpent and Jesus as a symbol of redemption. Furthermore, this paradoxical feature of the serpent was found in all types of mythology and religion, bringing to mind the importance of the serpent for individuals and in culture. In addition, serpents appear repeatedly in the dreams and fantasies of clients, as well as in sandplay. It has been observed that the appearance of the serpent brings strong emotional impact on the ego. The consciousness of the serpent, a cold-blooded animal, is quite distant from instinct, and calls for an urgent awareness of the instinctive aspect. The researcher has seen many instances of serpents appearing in sandplay sessions or in the dreams of clients. The appearances came with a dominating and strong influence on the consciousness, which led to questions about the meaning of these appearances. With an urge to gain a deeper understanding of serpents, I began the study on the symbolism of serpents.

This study looks into the biological characteristics of the serpent and the various myths, folktales, and religious documents in which serpents appear, with an aim to identify and examine the serpent as a symbol of the devouring unconscious, a symbol of the vitality of Libido, a symbol of feminine wisdom, and a symbol of regeneration and healing. The study also looks into the real-life interpretation and application of the symbolism of the serpent by examining the following two cases: the appearance of serpents in a dream of a female client suffering from depression after an early retirement, and the appearance of serpents in a sandpicture created by a young teenage boy with adjustment issues, who is raised by a controlling mother. 
Journal of Symbols \& Sandplay Therapy, Vol.11 No.1.

\section{П. BODY}

\section{A. Biological Characteristics of the Serpent}

Serpents are the cold-blooded reptiles of the suborder Serpentes. Serpents have a central nerve system, and their skeleton is made up of only the skull and a long spine, without any legs. Most reptiles have flexible spines. Serpents have no limbs, and slither with their thin and long cylinder-shaped bodies. Serpents do not interact with one another, and live alone their entire lives (https://namu.wiki/w/\%EB\%B1\%80).

Viper snakes come outside after sunset to hunt small animals such as mice or frogs. They use their heat-sensitive pit organs, located between the eyes and nostrils, to identify the location of the prey in the darkness of night and make a swift attack (Sim et al., 2007). Serpents feed on insects and vertebrates. Because they cannot chew or tear with their teeth, they swallow the prey whole. Serpents have jawbones that are connected to the ligament, which makes it easy to open their mouth very wide. Their bodies are also quite elastic, which makes it possible to swallow even large animals. Nonvenomous serpents generally attack and wrap their body around the prey to suffocate it, and small animals are swallowed whole (Sim et al., 2007).

Serpent bodies are covered with scales, and grow through a series of molting. A serpent sheds its skin several times a year, and more often when it has much to eat. Before a molt, the body of the serpent becomes cloudy and the skin becomes dull. The serpent rubs its body on rough surfaces, such as in between rocks or tree branches, to shed its skin (Sim et al., 2007).

Serpents are hibernating animals. When the weather gets cold, they move into places where they can keep safe from danger, such as under the ground or dark holes formed inside rocks. During hibernation, their body temperature goes down, and there is barely any heartbeat, breathing or muscle movement, thus minimizing energy loss. When the cold season passes, serpents wake up from their sleep and come out into the sunlight (Korea Britannica, 1993). Thus, serpents are most visible in the fall, when they are out hunting in preparation for the winter hibernation season, and spring, when they come out of hibernation to enjoy the 
sunlight (Sim et al., 2007).

Viper snakes and cobra snakes are venomous serpents. They use their venom to paralyze, swallow and digest the prey. Viper snakes in particular have venomous fangs that resemble syringe needles. When a viper snake opens its mouth, the fang stands and presses on a venom pocket, which releases the venom. Sea snakes have venom that cause neuro-paralysis. Sea snakes may thus be killed by the bite of another sea snake. Viper snakes have hemotoxin, which makes the area of the bite swell up and turn purple like a bruise. It is also difficult to stop the bleeding. When bit by a snake, it is important to consult a doctor immediately, get an injection of antitoxin and receive treatment for the bite (Sim et al., 2007). However, when properly extracted, the venom can be used not only as an antidote to bites from the same family of serpents, but also as an anticarcinogen and treatment for incurable diseases, and to make chemical products (https://namu.wiki/w/\%EB\%B1\%80).

\section{B. The Serpent as a Symbol of the Devouring Unconscious}

Among the many traits of the serpent, the way it devours a prey gives it its negative and destructive image. This devouring characteristic illustrates the serpent as an element of suffocation and growth prevention (von Franz, 2017). It is a destructive aspect that suffocates the child and prevents differentiation, and appears as the negative aspect of the uroboric mother archetype, which represents the unconscious. In myths and folktales, the devouring serpent is illustrated in the image of a destructive mother.

In Greek mythology, Gorgon is well known for her frightening appearance. The multiple serpents entangled on her head, the popping eyes and boar-like teeth are enough to give one the shivers. Anyone who looks into the fiery eyes of Gorgon stops breathing and turns into stone. Gorgon is also known as Medusa, which stands for "female dominator" (Kerenyi, 2002). It refers to the dominating power of the negative mother image that blocks the differentiation and development of a child who is trying to move forward in life. The fearsome serpent petrifies the human being and causes a regression into the unconscious.

Echidna is the mother of Sphinx and of all creation. The upper half of her body is a beautiful and attractive woman, but the lower half is that of a horrifying serpent, a 
Journal of Symbols \& Sandplay Therapy, Vol.11 No.1.

curse that has been put on her for committing incest (Jung, 2006). Sphinx is in fact the personification of herself as the "intimidating mother" or the "devouring mother" (Jung, 2006). The name Sphinx is derived from the Greek term for "to bind." As such, the Sphinx is a monster who abducts young children and petrifies anyone who lay eyes on her (https://terms.naver.com/entry.nhn?docId=1642031\&cid=60656\&categoryId=60656). She is the image of the intimidating mother, binding the child in the form of incest and preventing a differentiation to consciousness, displaying qualities of the unconscious. Hydra is another offspring of Echidna. He is a serpent with many heads, which grow back when cut off. The middle head is known to be immortal. The venom of Hydra is deadly, which even the Gods are afraid of (https://namu.wiki/w/\%ED $\% 9 \mathrm{E} \% 88 \% \mathrm{~EB} \% 93 \% 9 \mathrm{C} \% \mathrm{~EB} \% 9 \mathrm{D} \% \mathrm{BC}$ ). He is another example of the devouring mother image, which paralyzes and kills.

Sisutl is a two-headed serpent that appears in North American mythology. Sisutl also turns human beings into stone, but is known to be a guardian of the courageous (Moon, 1997). Here again, the serpent takes on the characteristics of the devouring mother that forces the regression of the human being. It is another good example of the unconscious characteristic of the serpent.

Another example is the boa constrictor from Antoine de Saint Exupery's Little Prince. The illustration of a boa swallowing a humongous elephant symbolizes the incredible dominance of the serpent. Here, the boa is a good representation of the negative mother archetype, which suffocates and hinders growth. It represents the unconscious regression that makes us step back, and shows how the unconscious can overpower, capture and devour (von Franz, 2017).

Neumann describes the devouring unconscious with the concept of uroboric incest: "Uroboric incest is a form of entry into the mother, of union with her, and it stands in sharp contrast to other and later forms of incest. In uroboric incest, the emphasis upon pleasure and love is in no sense active, it is more a desire to be dissolved and absorbed; passively one lets oneself be taken, sinks into the pleroma, melts away in the ocean of pleasurea Liebestod. The Great Mother takes the little child back into herself, and always over uroboric incest there stand the insignia of death, signifying final dissolution in union with the Mother." (Edinger, 2015, p59) 
The uroboric state is a state of union with the mother, in the form of early childhood ego that does not yet know itself. The child seeks to grow and become an adult, but if the child continues to depend on the mother due to weak vitality, the serpent will wrap itself around and suffocate the child (Jung, 2006). The unconscious is devouring, and is represented as a destructive mother who devours the child and tries to tie the child down into regression. This image of the unconscious can also be seen not only in dreams or illusions but also in mythology and folktales. Neumann has said that the unconscious appears as the terrible mother when liberation from consciousness is painful (Neumann, 2009). When this moment comes, the child is devoured by the mother.

When differentiation from the mother, or the serpent as the devouring unconscious, is not made, the child becomes even more attached to the world of the mother. The growing dependency could even lead to pathological conditions. For example, the child may become increasingly dependent on materials that represent the mother, and fall into substance abuse, such as alcohol or drugs (Rhi, 2005). Boys who are attached to the world of the mother show homosexual tendencies and may possibly become a lascivious man like Casanova (Rhi, 2005). They remain eternally as a boy attached to an ideal world. In German romanticism, it also takes the form of a yearning for death (Jung, 2002).

When the mother as the unconscious captivates the daughter, it either strengthens or weakens the mother, which exposes it to the risk of losing its nature (Jung, 2002). In mythology, a hero courageously defeats the horrible and devouring dragon or serpent, which represent "the negative image of the mother and a struggle against incest, or the anxiety and fear that follow," and also "a key symbol of the terrifying end to the violation of taboo, or regression into incest" (Jung, 2006). When this negative image of the mother is defeated, the collective society and civilization differentiates and becomes conscious (Neumann, 2010). The external appearance of the destructive aspect of the mother image brings about fear, but the negative mother image has its own purposeful meaning. The attack of the serpent stimulates the source of power that allows the hero to overcome fear and battle with courage. In that sense, the image of the devouring mother may be a tactic of Mother Nature to ensure that the hero in fact becomes a true hero (Jung, 2006). 
Journal of Symbols \& Sandplay Therapy, Vol.11 No.1.

\section{The Serpent as a Symbol of the Vitality of Libido}

The serpent appears as a form of instinctive drive, but it also appears as the positive aspect of the two aspects of the archetype, which is the psychic energy of creative vitality.

"Serpents and such beasts that bring vitality into a dream indicate the untamed and undifferentiated libido. The drive that comes from the instinctive aspect of animals come vividly to life and creates change in various directions. Like energy, libido also appears as a form of force, and it is a specific form of energy that appear in mobile objects. Libido is expressed in the way parts of personality is expressed, and appears with the intensity of impulse, affekte, and activity." (Jung, 2006, p268)

Kundalini, as in Kundalini yoga, symbolizes the serpent and represents the spiritual energy that flows inside the body (Bittlinger, 2010). The spot where the kundalini snake is coiled up and asleep is referred to as chakra, or the root of all fundamental energy (Bittlinger, 2010). "Linga," the image of the phallus worshiped in India, exists here as the seed of the creative psyche, while Kundalini is the sleeping princess who has not yet appeared and remains as a possibility. In this state, human beings are unable to see their shadow, believe that they are pure and faultless, and expect the gods to be asleep (Bittlinger, 2010). The purpose of Kundalini yoga is to awake Kundalini and to separate the gods from the world so that they can do their work. Meditation is focused on awakening Kundalini and making the energy of life flow so that the power of healing can grow. Indians believe that the spine is the key pathway of this energy flow. According to them, the energy originates from Mother Earth and flows along the spine all the way up to the sky. As Kundalini flows along the road from the root chakra to the crown chakra, the Mother Earth and sky unite, symbolizing the union of a "mother" and a "father" (Bittlinger, 2010).

In mythology, the road of Kundalini is portrayed as the union between Shakti and Shiva. Shakti is the feminine Kundalini energy that finds its center in and rises from the root chakra. Shiva finds its center in the crown chakra. Shiva accompanies and connects with Shakti from the root chakra, filling up each of the chakras along the way. Even at the root chakra, Shiva and 


\section{Kim, Nam Kyoung / Symbolism of Snakes that Stimulate Restoration and Transformation of Visceral Vitality}

Shakti appear together as a union of the terrestrial and celestial energies (Bittlinger, 2010). We can see the various appearances of the Self along the Kundalini pathway, which connects the lowest and the highest places, or the root chakra and the crown chakra. At times, the Self takes on the symbolism of a beast. In places where sexual desire is oppressed or overlooked, the Self may symbolize the phallus (Jung, 2016).

The serpent symbolized the male genital organ in ancient culture. The head of the serpent was associated with the glans. The millstone-shaped Yoni-Linga icon symbolized the sacred union of man and woman (https://ko.wikipedia.org/wiki/\%EB\%A7\%81\%EC\%97\%84). It was the serpent, or the seed of life, that entered the Yoni. In Egyptian hieroglyphics, the serpent represented the father, and appeared in myths as the creator of the grounds, guardian of the human race, and the phallus that roamed underneath the earth, making it fertile (Jacq, 1997). The serpent that symbolizes the phallus is the psychic vitality of the unconscious, and appears as the power that preserves the species and retains the value of productivity.

"It is characteristic that this priapic divinity returns again to the old symbol of the snake, which in the mystery enters into the faithful, fertilizing and spiritualizing them, although it originally possessed a phallic significance. In the mysteries of the Ophites, the festival was really celebrated with serpents, in which the animals were even kissed. In the sexual orgies of the modern Christian sects the phallic kiss plays a very important role” (Jung, 2006, p345). Here, phallic significance refers to the libido of the serpent, suggesting that an encounter with the serpent may involve an unconscious creative vitality. Thus, the mysteries were those that accepted the creative psyche.

\section{The Serpent as a Symbol of Feminine Wisdom}

The terrifying venom of the serpent and its seducing wickedness may lead us to death, but from another perspective, it awakens and broadens the consciousness, brings wisdom and bears a feminine wisdom that guides the spirit. In ancient times, serpents were considered agents of Mother Earth because they slithered on the ground with their stomachs, and a symbol of the womb, pregnancy, prolificacy, and abundance. The creativity of the serpent was likened to the role of ancient goddesses (Campbell, 2016). They were associated with the 
Journal of Symbols \& Sandplay Therapy, Vol.11 No.1.

serpent and were worshipped as serpent goddesses. The goddesses were also directly related to wisdom and prophecy. Melampus and Cassandria, prophets in Greek mythology, gained their prophetic powers after their ears were licked by serpents (Lee, 2002). Furthermore, there are stories of people with immunity from snake venom experiencing a divine revelation when bitten by the krait or cobra snakes, due to certain chemicals that make up the venom (Stone, 2005). As such, snake venom contains elements of numinosity, which brings spiritual transformation (Neumann, 2009).

Serpents are cold-blooded vertebrates phylogenetically located at the very bottom of the warm-blooded vertebrate system. The symbolism of the serpent thus suggests that the human consciousness is distant from the animal psyche in an unconscious state (Jung, 2016). The instinctive tendencies of these cold-blooded animals are revealed when women suddenly change their attitude and become cold, or mercilessly cut off a relationship (Jung, 2016). The shadow aspect of the serpent, which is on the opposite side of the psychic world, cannot be distinguished from the animal drive or instinct, or the lowest level of human character. Just as it is difficult to become aware of a shadow, the serpent is something entirely unconscious and therefore also difficult to become aware of. The Gnostics in fact considered the serpent as inferior as the reflex functions of the spinal cord and bone marrow (Jung, 2006). However, the serpent also symbolizes Jesus Christ, representing wisdom and supreme spirituality. As such, the serpent can be something of both the lowest and highest nature. The serpent displays a particular form of wisdom that comes from the collective unconscious and instinct, and bears the wisdom of life that comes from its supernatural instincts. It is this treasure that the serpent wishes to protect, and the reason why it is associated with evil and darkness from one perspective but wisdom from another (Jung, 2016).

The Book of Genesis claims that Adam and Eve were deceived by the serpent and fell into sin by eating the forbidden fruit. Gnostics argue that instead, "their eyes were open." Gnostics worship the serpent, and from their perspective, Eve is a wise woman and a true daughter of Sophia, who represent the wisdom of the skies. From this perspective, it was Eve who woke Adam from his sleep (Stephan, 2006). As the Gnostic sect Ophites believed, Adam and Eve were not thieves who picked the forbidden fruit, but heroes who sacrificed the comfort 
that comes from passive obedience for the greater consciousness. If more value is placed on consciousness rather than comfort, than the serpent becomes a beneficial creature. As such, the seduction and bite of the serpent may have resulted in the painful experience of expulsion from heaven, but it may also have brought about an expansion of consciousness (Edinger, 2016).

Another example can be found from the "Story of the White Snake," a legend passed down in Mongolia about the Hunter Hairab Rock. In this story, a white snake, the "daughter of the dragon king," was rescued from danger by a hunter named. To thank, she took him to her father. With the help of the white snake, was given a treasure that the dragon king was holding in his mouth, which allowed him to hear the voices of animals. One day, Hairab heard the animals talking about a huge flood that was coming toward the village. Even though he was forbidden to talk about his secret, he told the villagers the things the animals said. was then cursed and turned into a rock (Joo, 1999). As can be seen from this story, the white serpent is considered a sacred animal in the Far East. It is a feminine underworld element of the unconscious with divine powers. The white snake in the story is a spiritual guide who took the hunter to the dragon king. As the daughter of the one who oversees the collective unconscious, she carried feminine wisdom that brings the entire psyche into connection.

To alchemists, Hermes was a chthonic deity considered identical to Mercurius, who was like the wind and had characteristics of the chaotic underworld. Alchemists thought that the serpent symbolized a repetitive creation of the world. They believed that the serpent in the Garden of Eden was a crafty and evil Mercurius god, and that it was a demon that interfered with their work in all kinds of ways (Jung, 2016). However, in another way, the interference, the devilish character and the attack of the serpent served as a factor of development, driving changes in consciousness and civilization. The serpent symbolizes the dark underworld, but at the same time it is a symbol of wisdom, an animal of the light and the good, and a spiritual creature (Jung, 2016). 
Journal of Symbols \& Sandplay Therapy, Vol.11 No.1.

\section{E. The Serpent as a Symbol of Regeneration and Healing}

The ancient people thought that the serpent gained new life every time it shed its skin and grew. They believed that the serpent was immortal and had eternal life, and that therefore it is a sacred being (Campbell, 2000). The serpent was thus portrayed in the form of uroboros in Greek mythology, which represents regeneration. The uroboros is a serpent biting on its own tail. It is in a circular form, illustrating eternal life based on the repetitive cycle of swallowing, giving birth and regenerating. In Mystery religions the Sea of Deity (Meer der Gottheit) appeared in the form of the uroboros. Although there were concerns about the dismantlement of the ego or the ecstatic loss of the ego that comes from uroboric incest, there was also an understanding that it is a creative process that embodies the principle of rebirth, or Die and Become (Stirb und Werde). The uroboros is also a symbol of the cosmical union that is established when fullness is restored through a religious experience of the individual. It is the starting point of mythology, and a place of transformation, enlightenment and completion that symbolizes the wholeness and completeness that has been regained (Neumann, 2010).

The Egyptian Book of the Dead depicts a journey of the sun that passes through twelve chambers corresponding to the twelve hours of darkness. The sun first passes through a sandbank full of serpents, after which the rays themselves turn into serpents. On the seventh hour, the materialization of the underworld keeper in the form of a serpent, Apopis, appears. Its image is also that of Satan from the Old Testament. On the eleventh hour, the ropes of sunray turn into serpents, and on the final, twelfth hour, the sunrays in the chamber of dawn are pulled out by serpents. Once out of the serpent's mouths, the rising sun takes the form of a beetle lying on the breast of Mother Earth. The sun is born once again and rises to the sky (Chevalier et al., 1996). Here, the serpent regenerates the sun and allows it to be born again. It is a regenerator that leads the way from death to life, and from life to death.

According to Ad De Vries, the serpent represents the wheel of life in Buddhism. The Buddhists also depicted the serpent as swallowing its own tail. It is a representation of cosmic unity, self-sufficiency of the natural world, androgyny, continuation of life and the extinction of the body and matter (Publishing Committee for the Korean Culture Symbolism Dictionary, 2006). 
A similar example is found in Sutta Nipata, the first Buddhist scripture. Sutta Nipata is written in the form of a poem. The topic of the first chapter is "the metaphor of the serpent," and seventeen paragraphs are made up of a repetition of the words "abandon this world and that, like a serpent that sheds its skin" (Beop Jeong, 2005). The poem says that just as a serpent peels off its skin, our bodies come and go, and that there is no use for greed or obsession, because we will all be leaving the old house one day. The regeneration of the serpent indicates nirvana, or the liberation and enlightenment of the body and mind.

Another example of the serpent as a symbol of regeneration and immortality can be found in a shamanistic narrative myth from Jeju Island called Chasa Bonpuri. In the myth, a serpent that crawled out of a hole in a stone wall ate a book that the messenger of the underworld, a crow, had dropped. It is said that since then, the serpent became immortal, dying nine times but coming back to life the tenth time (Publishing Committee for the Korean Culture Symbolism Dictionary, 2006).

The duality of the serpent as a symbol of both life and death can also be seen in its venom. The bite of the serpent can be fatal if not treated immediately. However, if the venom is diluted many times, it can serve as a treatment that instead saves lives. As such, the venom of the serpent can both kill and heal. As Hippocrates said, "like cures like." Another key example of the serpent as a symbol of healing is the emblem of the World Health Organization (WHO), which depicts the "Rod of Asclepius" (https://namu.wiki/w/\%EC\%95\% 84\%EC\%8A\%A4\%ED\%81\%B4\%EB\%A0\%88\%ED\%94\%BC\%EC\%98\%A4\%EC\%8A\%A4). The son of Apollo, Asclepius was led to life from death the moment he was born. His mother, Coronis, was burned to death for infidelity during her pregnancy. Asclepius was taken out of her womb when she was placed in the firewood, thereby narrowly escaping death. The power of healing born from death belongs in the "wounded archetype." Carl Kerenyi psychologically describes the myth as a story of the "magical birth of Asclepius, a healer who resembles the sun, with the ability to feel comfort in the darkness of pain and discover the seed of light and recovery from within it" (Edinger, 2015). Asclepius was the god of medicine and healing who held the secrets to immortality (Campbell, 2016). He carried around with him a rod that had a serpent wrapped around it. With the help of Athene, he obtained the blood of Medusa and 
Journal of Symbols \& Sandplay Therapy, Vol.11 No.1.

used the blood from her left side to kill and blood from her right side to treat and restore life (Campbell, 2000). It is an example of how the blood of the serpent was used to both kill and save human lives.

Caduceus, or the Staff of Hermes, is a symbol of underworld transcendence and is widely known in the West as the symbol of medicine. Two serpents are intertwined around the staff. Jung learned the principle of disease treatment from this image of the tame and wild serpents battling each other (Publishing Committee for the Korean Culture Symbolism Dictionary, 2006). The Staff of Hermes also symbolizes death in time, and the power of life that discards the past and moves forward into the future (Campbell, 2016). At a glance, the Staff of Hermes resembles the Rod of Asclepius. However, the two have different purposes, with the former used to take the dead to the afterlife, while the latter is used to bring a dying person back to this life. (https://namu.wiki/w/\%EC\%95\%84\%EC\%8A\%A4\%ED\%81\%B4\% $\mathrm{EB} \% \mathrm{~A} 0 \% 88 \% \mathrm{ED} \% 94 \% \mathrm{BC} \% \mathrm{EC} \% 98 \% \mathrm{~A} 4 \% \mathrm{EC} \% 8 \mathrm{~A} \% \mathrm{~A} 4)$. This is analogous to how serpents spend the winter underneath the ground or in a deep cave and then come up above the ground when spring comes.

At the Temple of Asclepius, it was believed that dreams could heal diseases, similar to modern psychotherapy. It was believed that by taking a bath at the Temple and then spending the night at Abaton, a sacred sleeping room next to the Temple, healing would occur. Specifically, one would dream about a serpent biting on a wound, which brings healing, or God will appear and give directions on how to treat the disease (Rhi, 2005). The experience was thus a process to awaken the power of self-healing within a person and call on the healing power of the psyche. Thus, the dream was about the power of the serpent erupting from within, and at the same the healing power of God (Campbell, 2016).

In the Book of Numbers in the Old Testament, the serpent appears as a symbol of healing. On their way to the Promised Land, Moses and the Israelites were camping out on the vast fields. The joy of exodus was brief, and as life on the field got hard, the Israelites started to long for their old lives as slaves and blamed God. God punished them by sending fiery serpents that bit them. Moses asked God to forgive the sins of the Israelites, and God instructed Moses to set a bronze serpent on his pole. Anyone who laid eyes on the serpent was 
to live. The story contains yet another example of the dual aspect of the serpent. The fiery serpents represent the judgement of God on the Israelites who cursed Him, but the bronze serpent is a treatment God bestowed on those who repented (Walton et al., 2001). The bronze serpent is analogous to the image of Christ in the New Testament, who was placed on the cross to save the people. The image of the serpent is made up with images of venom and illness, but at the same time it contains an image of the instinct that brings healing and recovery.

\section{F. The Serpent in Dreams and Sandboxes}

\section{1) Case 1: The symbolic meaning of the serpent in a dream}

Jina (alias) is a woman in her forties who came into consultation for depression and lethargy after leaving her job of almost twenty years. She used to be an extrovert, adjusted well to social life, and had always been busy, diligently carrying out responsibilities at work. Then all of a sudden, she was laughing less, and was exhausted from the repetition of everyday life. The depression got worse, and when she started to long for death, she quit her job. During the consultation, Jina talked about a dream in which she vividly remembered the feel of serpents crawling on her body. The following is a description of her dream:

\section{[Dream 1]}

"I think I am in the deep woods. I seem to be in the middle of a game in which I need to pass each course to move on to the next one. I am with a girlfriend who is around my age but she is unfamiliar to me. We are being chased by two men who look like aboriginals (like native Indians). Another group of people who look like hunters are chasing after the aboriginals with guns in their hands. As we run, we find a place to hide. It is a tomb made of stone. The building is in the form a cross, and because it seems too easy to get caught behind the wall, we look for another place to hide. We go beneath the ground, open a door and hide inside a circular room. We are just catching our breath when the two aboriginals who were after us open the door and enter. I stop breathing the moment my eyes meet theirs. With their eyes sparkling, the men let open a pouch that they are holding, which is full of serpents. As the serpents crawl over my body, I close my eyes and pray to Jesus. "My life and death depend on you, so do whatever you want." I 
Journal of Symbols \& Sandplay Therapy, Vol.11 No.1.

am holding my friend's hand tightly. I had been calmly waiting, but as time goes by it gets increasingly difficult to endure the feeling of serpents wriggling across my body. So, with a stern voice, I tell the two men, "get rid of the serpents." I am not sure how my tone was, but the men say I do not look scared and take the serpents away. It feels like I had just passed a test. I think I hear voices of those trying to save us. Then, I find a small serpent trying to bite the side of my breast so I grab it by the head and throw it on the floor. The serpent has something white in its mouth. I think it might be underwear, and I come out of the room. Outside, I see a square stone door (that has letterings that I cannot comprehend). A black belt that lay outside the door disappear into the door as if a serpent is dragging it in."

In this dream, the multi-course game indicate that the dreamer is in some sort of transition. The two aboriginal men represent the primitive, undifferentiated masculine elements that have not yet developed, and the group of men with the guns are the unconscious masculine elements that are goal-oriented and civilized, which allow the dreamer to interact with the external world with a goal-oriented attitude (Boa, 2004). The cross-shaped tomb may be interpreted as an initiation or a place of transformation that descends into death (Jung, 2004). When the primitive men set the serpents free inside the tomb, the dream psyche is unable to move. The serpents may serve as an image that stimulates visceral vitality, but at the same time if could be an image that stimulates the feminine wisdom that allows one to stay in one spot and endure the depression and process of death. After the endurance is over, the dream psyche feels as if it had just passed a test. Then, as the dreamer tries to stand up, she finds a small serpent biting on her chest. The act of a serpent biting on the underwear of a woman around her chest may be considered a stimulation of new insight on the feminine fundamentals (Edinger, 2016). In the dream, the serpent stimulates the body of the dreamer who is suffering from lethargy and depression. At the same time, it triggers feminine wisdom and consciousness by biting on a piece of underwear near her breast. The serpent in the dream seems to awaken the feminine wisdom and the principle of eros, or the feminine fundamentals, while also driving a new transformation of the consciousness. The fundamentals of the feminine principle involve an acceptance of life, creating relationships and blending in with nature or the unconscious. After many years of career building and childbearing, Jina was unable to enjoy retirement or accept the life of a woman. For her, the serpent dream seemed to have 
stimulated a new transformation of consciousness by enlightening her on the meaning of feminine wisdom and feminine fundamentals.

\section{2) Case 2: The symbolism of the serpent in sandplay}

Minwoo (alias) is a boy in his early teens. He was raised by strict parents who interfered and lectured, and had problems with friends at school. He had low self-esteem, and was lethargic and depressed. He did not want to go to school, and his homeroom teacher advised him to receive therapy. During the first sandplay session, Minwoo took a large serpent figure and wrapped it around his neck, shook it around as if fascinated by it, and made it slither across the floor. He also made threatening gestures by pretending to throw the serpent figure at the therapist. He placed the large serpent in the middle upper half of the sandbox and placed a group of smaller serpent figures on the left lower half, declaring that it is a world of serpents. As Minwoo told a story about his sandbox, he touched the figures as if playing with them. He said that the serpents created a circle and killed all the soldiers. According to him, the world became one of serpents and crocodiles. A serpent fighting with the crocodile got bit on the neck. Minwoo than brought with him an armful of people figures and placed them on the right lower half of the sandbox. He placed an ax in the crocodile's mouth and said that the people were trying to cut the serpents in slices. He also said pirates were coming. Saying that the crocodile and serpents were dying, he declared that the people in armor had won the battle. The following is a photograph of Minwoo's sandbox.

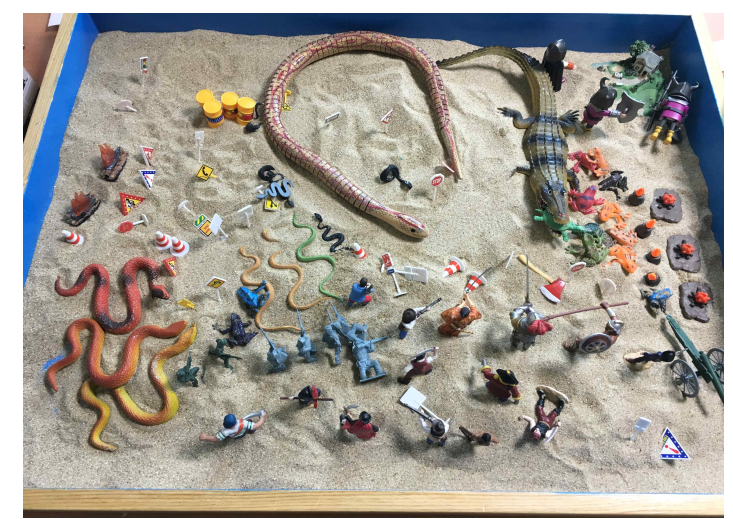

Sandpicture 1. 
Journal of Symbols \& Sandplay Therapy, Vol.11 No.1.

Minwoo played with the serpent figure in the middle of the sandbox and pretended to throw it at the therapist. This may demonstrate a fondness for serpents, but it may also indicate the unconscious impact of the serpent instinct. The serpents that appeared on the sandbox may be interpreted as an image of the unconscious underworld instinct that is distant from humanness. The significant number of serpent figures suggests that the instinct of the serpent is active, and that it is dominating. The serpent demonstrates a threatening quality, being able to swallow crocodiles and other animals. The activeness of the cold-blooded animals indicate that Minwoo has a tendency to be dominated by instinctive power, and that in real life Minwoo has irritable, impulsive and offensive tendencies.

Minwoo had been in fact diagnosed with and took medication for ADHD during his first year of elementary school. According to his mother, he "beat up friends or snatched balls from them when they left him out." Whenever Minwoo caused problems at school, his mother tried to solve the situation by changing schools or moving to another neighborhood. She let problems between Minwoo and his friends become a bigger problem between adults and put Minwoo in a difficult position. It seemed that the dominance of the negative mother archetype was preventing the differentiation of consciousness and growth. However, in his sandbox Minwoo created scenes of men aiming guns at the serpents and a person with an ax trying to slice the large serpent, which demonstrate a struggle to respond to the serpent, or the devouring unconscious instinct. The use of these masculine principles indicate that differentiation is gradually taking place. Minwoo's sandpicture suggests that there is an attempt to differentiate and separate from the instinctive tendencies of the unconscious, and that it is being manifested.

\section{CONCLUSION}

This study looked into the significant meaning the serpent presents in most myths, religion and minds of the human being. The devouring quality of the serpent becomes an unconscious image that blocks the differentiation and development of consciousness when 
liberation from consciousness is difficult. It appears as a destructive aspect that attempts to keep one in the unconscious. The seduction and bite (attack) of the serpent is in itself painful, but it also brings an insight into and expansion of consciousness, and presents an opportunity to transport life that is rooted in Mother Earth and reality. The serpent is also an unconscious underworld element with feminine wisdom that connects the unconscious elements excluded from consciousness with the entire psyche. The serpent also symbolizes the phallus, which is the seed of life. It thus represents libido as an unconscious psychic vitality. Therefore, an encounter with the serpent brings unconscious creative vigor and restores vitality. Furthermore, the serpent is an archetype of healing. It is a regenerator that drives the process from death to life and life to death, and is a symbol of healing and recovery. The serpent contains aspects of the dark underworld and destruction, but the wisdom of the serpent also serves as a creative element. Just as Isis created a venomous serpent to bite but was also a healer who could treat the bite, the serpent is venomous but at the same time it can make things heal. The serpent thus holds a holistic image that comes from its paradoxical nature.

In the case of the female client, the serpents that appeared in her dream presented psychic vitality and the energy of regeneration, stimulating the consciousness. The dream left the unpleasant feeling of serpents crawling on her body, but the encounter awakened the bodily senses that were asleep. The encounter with the serpent stimulated the psychic energy of the unconscious creative vitality.

In the case of the teenage boy, the serpent that appeared in his sandpicture represents the unconscious aspect of its devouring nature. When this aspect is activated in a dominating way, a child may have difficulty in differentiating and developing the consciousness. At times, this may appear as a pathological element. However, by encouraging the child to face and overcome the aspect of the serpent, a new development of the consciousness can be made possible.

A look into the symbolism of the serpent was helpful in exploring what kind of intentions and effective prescriptions are offered by the unconscious. The appearance of the serpent may be interpreted as an urgent call of the unconscious to make a change. The examination of the serpent in this study was greatly helpful in making sense of clients' 
Journal of Symbols \& Sandplay Therapy, Vol.11 No.1.

sandpictures and dreams in the clinical setting. It provided much insight and presented a small answer to the many questions the researcher had. However, the examination by itself will not be able to define all aspects of the meaning of the serpent. That is simply impossible. However, it can at least offer some kind of guidance to therapists who wish to learn the about general characteristics of the serpent.

The serpent is an image in the unconscious that exists in an area that human beings ignore, repress and isolate. It is a symbolism that appears to create a balance in our holistic being and guides us throughout the uneven process of individuation. The serpent is a holistic symbol of death and life, healing and recovery. Thus, the serpent is an image of the Self that connects the lowest and highest places. The Self is the "psyche that mysteriously guides our destiny" (Jung, 2016), which allows us to reveal our true self, grow (So, 2018) and move toward wholeness with symbolism.

\section{References}

BeobJeong. (2005). Suttanipata. Paju: Ire.

Shim, J-H., Kim, J-B., Min, M-S., \& Park, B-S. (2007). An illustrated guide of amphibians and reptiles. Paju: Borie.

Rhi, B-Y. (2005). Analytical psychology. Seoul: Ilchokak.

Lee, Y-K. (2002). Greek Roman myth. Seoul: Jakkajungsin.

Joo, C-Y. (1999). Mongolian oral tale. Seoul: Baeksan.

Dictionary of Korean Cultural Emblems Compilation Committee (2006). Dictionary of Korean Myths and Symbols 1. Seoul: Doosan Dong-A.

Korean Britannica (1993). Britannica world encyclopedia. Seoul: Woongin Books.

Bittlinger, A. (2010). Carl G. Jung and chakras (Translated by Choi, YeoWon). Changwon: Bhagavan Sri Ramana Maharshi Center in Korea.

Campbell, J. (2013/2016). Goddesses (Translated by Goo, HakSeo). Paju: Chungabook.

Campbell, J. (1968/2000). The masks of God Vol. III: Occidental mythology (Translated by Jung, 
YoungMok). Seoul: KachiBooks.

Chevalier, J. \& Gheerbrant, A. (1996). The penguin dictionary of symbols. London: Penguin Books. Jacq, C. (1997). Egyptian hieroglyphic story (Translated by Kim, JinKyeong). Seoul: JeMoon.

Edinger, E. (2015). Alchemical symbolism in psychotherapy (Translated by Kim, JinSook). Seoul: DonHwaMoon.

Edinger, E. (1972/2016). Ego and archetype (Translated by Jang, Mikyung). Seoul: Hakjisa.

Boa, F. (1988/2004). The way of the dream (Translated by Park, HyunSoon \& Lee, ChangIn).

Seoul: Hakjisa.

Jung, C. G. (1989). Mysterium Coniunctionis, C.W.14. Princeton: Princeton University Press.

Jung, C. G.(1984/2002). Grundwerk C. G. Jung Bd.2 Archetyp und UnbewuKtes (Translated by Korea Jung Institute). Seoul: Sol Press.

Jung, C. G. (1985/2006). Grundwerk C. G. Jung Bd. 8 Heros und Mutterarchetyp (Translated by Korea Jung Institute). Seoul. Sol Press.

Jung, C. G. (2016). Aion (Translated by Kim, SeYoung \& Jung, MyeongJin). Seoul: Boogle Books.

Jung, C. G. (2018). Interpretation of Vsions (Translated by Jung, MyeongJin). Seoul: Boogle Books.

Kerenyi, K. (1997/2002). Die Mythologie der Griechen (Translated by Jang, Youngran, Kang Hoon). Seoul: Kungree.

Moon, B. (1997). An encyclopedia of archetypal symbolism (Vol.1). Boston: Shambala.

Neumann, E. (2010). Ursprungsgeschichte des Bewusstseins (Translated by Lee, YooKyeong). Seoul: Analytical Psychology Center.

Neumann, E. (2009). The great mother. Paju: sallimbooks.

So, B-H. (2018). The staff as symbol of spiritual guidance for individuation, Journal of Symbols \& Sandplay Therapy, (2), 43-59.

Stephan, A. H. (2006). Gnosticism (Translated by Lee, JaeGil). Seoul: Shanti.

Stone, M. (2005). When God was a woman (Translated by Jung, YoungMok). Seoul: Puriwaipari.

Turner, B. A. (2009). The handbook of sandplay therapy (Translated by Kim, Taelyeon). Seoul: Hakjisa. 
Journal of Symbols \& Sandplay Therapy, Vol.11 No.1.

von Franz, M. L. (2002/2017). Puer aeternus (Translated by Hong, SookGi). Seoul: Jung Institute of Korea.

von Franz, M. L. (1980). Alchemy. Toronto: Inner City Book.

von Franz, M. L. (1999). Archetypal dimensions of the psyche. Boston: Shambhala.

Walton, J. H., \& Mattthews. V. H., \& Chavalas, M. W. (2001). The IVP bible background commentary (Translated by Jung BaeOk). Seoul: IVP

인터넷 검색

Snake(2019, Sep 20). Retrieved from https://namu.wiki/w/\%EB\%B1\%80

Sphinx(2019, Sep 20). Retrieved from

https://terms.naver.com/entry.nhn?docId $=1642031 \&$ cid $=60656 \&$ categoryId $=60656$

Hydra(2019, Sep 20). Retrieved from

https://namu.wiki/w/\%ED\%9E\%88\%EB\%93\%9C\%EB\%9D\%BC

Asclepius(2019, Sep 20). Retrieved from

https://namu.wiki/w/\%EC\%95\%84\%EC\%8A\%A4\%ED\%81\%B4\%EB\%A0\%88\%ED\%94\%BC\%

ЕC\%98\%A4\%ЕC\%8A\%A4

Yoni Linga(2019, Sep 20). Retrieved from

https://ko.wikipedia.org/wiki/\%EB\%A7\%81\%EC\%97\%84

Received : March 30, 2020

Revised : May 09, 2020

Accepted : May 13, 2020 
상징과모래놀이치료, 제 11 권 제 1 호

Journal of Symbols \& Sandplay Therapy

2020, 6, Vol. 11, No. 1, 213-230.

doi https://doi.org/10.12964/jsst.20005

\title{
본능적 활력의 복원과 변환을 자극하는 뱀의 상징성 Symbolism of Snakes that Stimulate Restoration and Transformation of Visceral Vitality
}

\author{
김 남 경*
}

Kim, Nam Kyoung

\begin{abstract}
$<$ Abstract $>$
Snakes are animals that often appear in religion, mythology, and fairytales. In these stories they have both sacred and destructive qualities. Snakes also appear as powerful emotions in individual dreams and sandplay cases. These snakes appear when consciousness is quite separated from instinct and provide an individual with a crucial opportunity for development and regression. Therefore, this study amplified various symbols of snakes and examined their meanings.
\end{abstract}

Keywords : snake, sacred and destructive qualities, powerful emotion

* 성남아동발달교육지원센터 상담사 (godotess10@Daum.net) 
Journal of Symbols \& Sandplay Therapy, Vol.11 No.1.

\section{I. 서 론}

르네상스 이후 신의 정신으로 이해했던 천동설적 세계관이 퇴색하고, 인간의 정신이 태 동하면서 인간의 의식이 발전하게 되었다(Jung, 2002). 그러나 근대 이후 인간은 의식의 일 방성과 합리성을 중요시한 나머지, 의식의 근원인 무의식을 무시하게 되었고, 한 낱 의식의 산물로 무의식을 취급함으로써 본능과 충동을 저급한 요소로 대하기에 이르렀다. 그로 인 해 현대인은 과학과 기술의 편리함을 외적으로 누리고 있지만, 마음은 그 근원과 멀어지며 생활의 활력과 삶의 의미도 잃어 가고 있다.

고대인들과 원시인들에게 동물은 하나의 신상(神像)으로 숭배의 대상이었고, 종교의 근원 이었다. 그들은 사냥을 나가기 전에 먼저 동물에게 의례를 행하였고, 만일 의례 시 문제가 발생하면 사냥에 나가지 않았다(Von Franz, 1980). 그들이 가진 동물에 대한 종교적인 숙고 의 태도를 통해, 자신 내면의 본능적 측면이 가진 신성력을 고려했음을 엿볼 수 있다. 문명 의 발달과 함께 신상(神像)도, 동물 형태에서 동물과 사람의 신(animal-people gods) 그리고 사 람의 모양으로 변해 왔는데, "이는 인간의 행동 특성을 의식화했던 과정 속에서 의식의 발 달을 반영한다” (Von Franz, 1999). 계통 발생적으로 이런 문명과 종교의 변환은 한 개체 안 에서도 동일한데, 마음이 의식을 향한 여정을 시작함에 따라, 마치 인류의 진화 과정과 같 은 유사한 세상의 진화를 다시 경험한다고 볼 수 있다(Turner, 2009).

동물은 합목적적인 충동성을 가지고 집단 무의식의 법칙을 충실히 실현해 가는 존재이 다. 이런 의미에서 동물은 인간 이하의 본능적이고 충동적 존재일 뿐 아니라, 인간성을 뛰 어넘는 신성함을 지닌 것으로 볼 수 있다. 집단 무의식의 내용은 원형과 본능으로 이루어 져 있고, 이 생명 현상은 떼어낼 수 없을 만큼 긴밀하게 이어져 있다(이부영, 2005). 무의식 의 한 부분인 본능은, 이런 면에서 우리가 알 수 없는 많은 것을 담고 있으며, 의식이 놓치 고 있는 근원의 것들과 연결되게 하고, 인간을 생생하게 살아가게 하는 원동력이 될 것이 다. 융은 동물의 상징을 "짐승이 등장하는 상징 체계는 언제나 동물의 차원에서, 즉 본능의 영역에서 발생하는 정신적 과정의 조짐이며," (Jung, 1989) “무의식성 속에 있는 동물은 인 간에게는 일찍부터 육체적인 충동 생활의 어둠 속에 감추어져 있는 정신 영역의 상징” (Jung, 2002)으로 이해했다. 이런 동물은 정신 과정에서 지대한 역할을 감당하는 것이다. 대 부분의 신화와 종교, 전설과 민담 속에 등장하는 동물 중에서 뱀은 그 특별한 지위를 지니 고 있다. 연구자는 성서에 등장한 뱀의 역설적인 상(像)을 알았을 때 신선한 충격을 경험한 적이 있다. 뱀이 인간을 타락의 길로 안내하는 파괴적인 악마적 특성을 이야기하면서도, 구 원의 상징으로 그리스도를 표현한다는 것에 놀라지 않을 수 없었다. 이런 뱀의 역설적 특 성이 모든 신화나 종교에서 발견된다는 사실을 발견했을 때, 뱀이 얼마나 개인과 문화에서 얼마나 중요한 지를 깨닫게 되었다. 또한 내담자의 꿈이나 공상, 모래놀이에서 뱀이 반복적 
으로 등장하는 것을 목격하게 되었다. 이런 뱀의 출현으로 자아에게 강력한 정서적 영향력 을 끼치는 것을 관찰할 수 있다. 냉혈동물로서 뱀은 의식이 본능과 멀리 떨어져 있고, 시급 하게 본능적 측면의 인식을 촉구하고 있는 것임을 짐작할 수 있었고, 대단히 결정적인 순 간임을 직감적으로 경험할 수 있었다. 그래서 개인과 문화에서 뱀의 출현이 가지는 의미에 대한 궁금증이 있었고, 뱀에 대한 보다 깊은 이해를 가질 필요성을 느끼게 되면서 뱀의 상 징연구를 시작하게 되었다.

본 연구에서는 뱀의 생물학적 특성과 더불어 뱀이 등장하는 신화, 민담, 종교 문헌 등을 고찰하면서, 집어삼키는 무의식으로서 뱀, 리비도 활력으로서 뱀, 여성적 지혜로서의 뱀, 재 생과 치유로서의 뱀으로 분류하여 탐색을 시도하고자 하였다. 또한 심리치료의 사례에서 직장을 명예퇴직하고 우울함 속에 있었던 40대 초반 여성 내담자의 꿈에 나타난 뱀과 통제 적 어머니 밑에서 적응의 어려움을 겪고 있었던 10 대 초반 소년의 모래상자에 나타난 뱀을 다루면서, 뱀의 의미가 실제적으로 어떻게 해석 적용될 수 있는 지를 살펴보고자 한다.

\section{ㅍ. 본 론}

\section{1. 뱀의 생물학적 특성}

뱀은 냉혈동물로서 뱀 아목에 속하는 파충류의 총칭으로, 중추 신경계를 가지고 있다. 골 격은 다리가 없고, 두개골과 긴 등뼈로만 이루어졌다. 대부분의 파충류는 유연한 등뼈를 가 지고 있다. 팔과 다리가 퇴화하여 몸으로 기어 다니고, 몸의 형태는 가늘고 긴 원통 모양이 다. 뱀은 서로 상호작용이 없으며, 평생을 혼자 산다(https://namu.wiki/w/\%EB\%B1\%80).

뱀 중 살모사는 해가 지고 어두워지면 밖으로 나와서 쥐나 개구리 같은 작은 동물을 잡 아 먹는다. 깜깜한 밤에도 눈과 콧구멍 사이에 있는 피트기관으로 먹잇감의 체온을 느끼고 쫓아가 잡는다. 그래서 어둠 속에서도 잽싸게 사냥을 할 수가 있다(심재한 외, 2007). 뱀의 먹이는 곤충이나 척추동물인데, 이가 먹이를 씹거나 뜯어 버리는데 적합하지 않아 먹이를 통째로 삼켜 버린다. 턱뼈가 인대로 연결되어 크게 벌릴 수 있으며, 몸통의 신축성도 좋아 큰 먹이도 통째로 먹을 수 있다. 일반적으로 독이 없는 뱀은 포획물에게 덤벼들어 몸통으 로 감아 죄어서 질식시키고, 작은 먹이는 통째로 삼킨다(심재한 외, 2007).

뱀의 몸은 비늘로 덮여 있어 허물벗기를 되풀이하며 성장한다. 뱀은 한해에도 몇 번씩 허물을 벗고, 먹이를 많이 먹을 수록 허물을 자주 벗는다. 허물을 벗을 때가 되면 몸이 뿌 애지고 몸빛이 탁해진다. 그러면 돌 틈이나 나뭇가지처럼 거칠거칠한 곳에 몸을 문대면서 허물을 벗는다(심재한 외, 2007). 
Journal of Symbols \& Sandplay Therapy, Vol.11 No.1.

뱀은 동면하는 동물로 날씨가 추워지면 땅속이나 바위 속의 어두운 구멍 등 위험을 피할 수 있는 장소로 들어간다. 동면 시에는 체온이 낮아지며 심장박동, 호흡, 근육운동이 거의 없어 에너지의 손실이 최소화가 된다. 추운 시기가 지나면 깨어나 태양빛을 받으러 밖으로 나온다(한국 브리태니커, 1993). 따라서 우리가 뱀을 자주 보는 시기는 겨울잠을 자기 전, 사냥을 다니는 가을 뱀과 겨울을 나고 일광을 나온 봄 뱀이다(심재한 외, 2007).

뱀 중 살모사과, 코브라과, 뱀과의 독은 먹잇감을 꼼짝 못하게 마비시켜서, 삼키고 소화 시키기 좋게 만든다. 독사 중 살모사는 앞니에 주사 바늘처럼 생긴 독니가 있다. 입을 벌리 면 이빨이 일어서면서 독니 주머니를 눌러 독물이 나오게 된다. 바다뱀은 신경을 마비시키 는 독이 있어서 서로 물면 죽기도 한다. 살모사 무리 독은 혈액성 독이다. 물린 곳은 부어 오르고 타박상을 입은 것처럼 자줏빛을 띠고, 물린 자국에서는 피가 안 멈추고 계속 흘러 나온다. 뱀에 물렸을 경우는 빨리 병원에 가서 항독소 주사를 맞고 치료해야 한다(심재한 외, 2007). 하지만 뱀의 독은 잘 채취해 사용하면 그 종의 해독제는 물론이고 항암제, 난치 병 약 및 화학 제품에 사용된다(https://namu.wiki/w/\%EB\%B1\%80).

\section{2. 집어 삼키는 무의식 상징으로서의 뱀}

뱀의 여러 특성 중에 집어 삼키는 요소는, 뱀의 부정적이고 파괴적인 특성을 드러낸다. 이런 집어 삼키는 뱀의 특성은 삶의 숨통을 막히게 하고, 성장을 가로막는 요소를 나타낸 다(von Franz, 2017). 아이를 질식하게 하고 분화를 가로막는 파괴적인 뱀의 측면은, 무의식 을 대변하는 우로보로스 모성원형의 부정적 측면으로 나타난다. 이런 집어삼키는 뱀의 특 성은 신화나 민담에서 파괴적인 모성상(像)으로 등장한다.

그리스 신화에 나오는 고르곤은 무시무시한 얼굴로 널리 알려져 있다. 머리에는 수많은 뱀이 꼬여 있고, 툭 튀어 나온 눈, 멧돼지같이 뾰족한 이를 드러내고 있어 보는 이를 공포 에 떨게 한다. 또한 고르곤의 강렬한 눈과 마주친 사람은 숨을 쉬지 못하고, 그 자리에서 돌이 된다. 고르곤의 또 다른 이름인 메두사는 “여성 지배자"를 뜻하기도 한다(Kerenyi, 2002). 이는 아이가 삶의 내용을 전개시키려고 할 때, 아이의 분화를 가로막고, 발전하지 못 하도록 만드는 부정적 모성상이 가진 지배력을 의미한다. 이런 무시무시한 뱀은 인간을 돌 같이 경직화시킴으로써 무의식으로 퇴행시키는 요소라 할 수 있다.

스핑크스의 어머니이자 모든 만물의 어머니 에키드냐(Echidna)는 상체는 아름답고 매력적 인 여인의 모습을 하고 있지만, 하체는 근친상간을 금한 것 때문에 끔찍스러운 뱀으로 변 한 무시무시한 반쪽으로 이루어져 있다(Jung, 2006). 스핑크스는 다름 아닌 그녀 자신을 나 타낸 '무서운 어머니', '잡아먹는 어머니'를 의인화한 것이다(Jung, 2006). 스핑크스의 이름은 그리스어의 '단단하게 묶다' 에서 유래되었는데, 이는 스핑크스가 어린 아이를 유괴하는 괴 
물로 여겨졌고, 이 괴물을 보면 꼼짝할 수 없다는 데서 나왔다고 한다(https://terms.naver.com/ entry.nhn?docId=1642031\&cid=60656\&categoryId=60656). 그녀는 잡아먹는 무서운 어머니 상(像) 으로 아이를 근친상간적으로 묶어둠으로써 의식으로의 분화를 가로막는 무의식적 특성을 나타낸다. 또한 에키드냐의 자식으로 여겨지는 히드라 역시 머리가 여러 개 달린 뱀으로, 머 리가 잘리면 다시 자라나고, 게다가 가운데 머리는 불사의 머리라고 한다. 심지어 신조차도 무서워하는 맹독을 가지고 있다.(https://namu.wiki/w/\%ED\%9E\%88\%EB\%93\%9C\%EB\%9D\%BC). 이런 뱀의 측면 역시 집어삼키는 어머니의 상으로 인간을 마비시키고 죽게 하는 특성을 지 닌다.

북아메리카 신화에서는 머리가 두 개인 뱀 씨서틀(Sisutl)을 볼 수 있는데, 씨서틀은 인간 을 돌로 만들어 버리고, 용감한 자의 수호자 역할을 했다고 한다(Moon, 1997). 이런 뱀의 측 면도 집어삼키는 모성적 특성으로 인간을 퇴행시키며 자신의 손아귀로 사로 잡는 뱀의 무 의식적 특성을 잘 보여준다.

쌩덱쥐베리의 <어린 왕자>에도 엄청나게 큰 보아 뱀이 나온다. 보아 뱀이 덩치 큰 코끼 리를 삼키는 것은 모성이 가진 어마어마한 지배력을 상징한다. 보아 뱀은 그의 숨통을 막 히게 하고, 자라나지 못하게 하는, 부정적 모성 원형의 형태를 잘 보여준다. 그것은 우리를 뒷걸음치게 만드는 무의식적 퇴행을 나타내고, 무의식에 압도되면 거기에 사로잡혀 죽음이 이를 삼켜 버린다는 것을 보여준다(von Franz, 2017).

이런 집어삼키는 무의식의 뱀의 특성을 노이만은 우로보로스 근친상간의 개념으로 설명 한다.

“우로보로스적인 근친상간은 모성 안으로 진입하는 하나의 형태로써 나중에 나 타나는 근친상간의 형태와는 다르게 모성과의 결합으로 나타난다. 우로보로스적인 근친상간에서 쾌락과 사랑은, 어떠한 능동적 의미를 갖지 않고 스스로 모성 안으로 용해되고 흡수되려는 것이다. 이것은 자신을 점유하도록 맡기는 수동적 형태이고, 플레로마(pleroma)에 침잠하여 쾌락의 대양에 용해되고 기꺼이 죽음을 맞이하는 일 종의 사랑의 죽음(Liebestod)에 해당한다. 태모(Great Mother)는 언제나 작은 아이들을 자신 안에 넣어서 모성(the Mother)과 합일하게 하여, 결국은 사라지게 하는 죽음의 표지를 우로보로스적 근친상간 위에 세운다.” (Edinger, 2015, p59)

여기서 우로보로스적 상태는 모성과 하나된 상태, 여전히 모성 곁에서 아직 자기 자신을 알지 못하는 초기 유아적 자아의 형태이다. 아이는 자라나 성인이 되고자 하는데, 아직도 아이가 미약한 생명력을 가지고 있어 어머니에게 계속 의존하고자 한다면 뱀은 아이를 돌 돌 말아 숨을 조여 버릴 것이다(Jung, 2006). 이때 무의식은 집어삼키려는 특성으로, 어머니 
Journal of Symbols \& Sandplay Therapy, Vol.11 No.1.

가 아이를 집어삼키고 퇴행적으로 묶어 두려는 파괴적인 태모로 나타난다. 이런 무의식의 상(像)은 꿈이나 환상뿐만 아니라 신화, 민담에서도 볼 수 있다. 노이만은 의식으로부터의 해방이 고통스러울 때에 무의식이 공포의 어머니로 나타난다고 기술하였다(Neumann, 2009) 이런 순간이 아이에게 닥친다면 집어삼키는 어머니에게 먹혀버릴 것이다.

만약 아이가 이런 집어삼키는 무의식으로서의 뱀인 어머니로부터 분화되지 않는다면, 어 머니의 세계에 부착됨으로써 의존적 관계는 더욱 강화되고, 병리적인 현상으로 드러날 수 도 있다. 어머니를 대변하는 물질에 더욱 의존적이 되고, 물질 남용과 같은 알코올이나 약 물 중독에 빠지게 된다(이부영, 2005). 어머니 세계에 부착된 남성들은 동성애적 성향, 카사 노바 같은 호색한이 되기(이부영, 2005)도 하고, 늘 이상적 세계에 부착된 영원한 소년으로 남게 된다. 그런데 때로는 독일의 낭만주의에서 죽음을 동경하는 현상 등으로 나타나기도 한다(Jung, 2002).

무의식으로서 모성이 딸을 사로잡을 때는 모성을 강화하거나 약화시키는 쪽으로 흘러 자 신의 본성을 잃어버릴 위험에 노출하게 된다(Jung, 2002). 하지만 신화에 나오는 영웅은 무 섭게 집어삼키는 용이나 뱀을 용감하게 물리친다. 이 때 용과 뱀은 “부정적인 어머니상으 로 근친상간에 대한 저항, 혹은 그에 대한 불안 공포를 나타낸다. 또한 금기를 위반했을 때, 즉 근친상간으로 퇴행했을 때 이에 따르는 결과에 대한 공포를 상징하는 대표적인 상 징”을 나타낸다(Jung, 2006). 이런 부정적인 어머니 상을 물리침으로써 집단과 문명이 분화 되고, 의식화되어 간다(Neumann, 2010). 겉으로 보이는 모성상의 파괴적 측면은 우리의 두려 움을 자극하지만 부정적 모성상도 나름대로 목적의미를 지니고 있다. 뱀의 공격은, 영웅이 두려움을 극복하고 용기를 내어 싸울 수 있는 힘의 근원과 연결되게 하고, 마침내 목적 의 미를 달성하게 하는 힘을 얻게 한다. 이런 면에서 집어 삼키는 어머니 형상은 영웅을 진정 한 영웅으로 만들기 위한 어머니 자연(Mater Natura)의 술수라고 볼 수 있다(Jung, 2006).

\section{3. 리비도 활력의 상징으로서의 뱀}

뱀은 동물의 본능적인 영역에서 충동성의 한 형태로 드러나기도 하지만, 원형의 이중적 측면 중, 긍정적 부분으로 창조적 활력의 정신적 에너지로 나타나기도 한다.

“꿈속에서 활기를 주는 뱀과 같은 짐승들은 아직 길들여지지 않은, 분화되지 않 은 리비도를 의미한다. 동물의 본능적인 영역에서 나오는 충동성은 생생하게 살아 나서 다양한 방향으로 변하게 한다. 에너지처럼 리비도도 힘의 형태로 나타나는데, 움직이는 물체들에서 보이는 특정한 에너지 상태이다. 리비도는 인격 부분들처럼 표 명되며, 욕동(Impulse), 정감(Affekte), 활동성 등의 강도로 나타난다(Jung, 2006, p268)." 
쿤달리니 요가에서 쿤달리니는 뱀의 상징으로 몸에 흐르는 영적 에너지를 나타낸다 (Bittlinger, 2010). 뱀이 똬리를 틀고 잠들어 있는 자리는 근원적인 모든 에너지가 담겨 있는 뿌리 차크라이다(Bittlinger, 2010). 인도에서 숭배되는 남근상인 '링가'는 뱀의 상징으로, 창조 적 정신의 씨앗으로 그곳에 있고, 잠자는 공주인 쿤달리니는 아직 나타나지 않은 가능성으 로 있다. 이 상태에서 인간은 자신의 그림자를 보지 못하고 자신이 순결하며 결점이 없다 고 생각하며, 신은 아직 잠들어 있다고 여긴다(Bittlinger, 2010). 요가의 목적은 쿤달리니를 일깨우는 것에 있고, 신들을 세상으로부터 분리시켜 활동하도록 하는데 있다. 명상에서는 이 쿤달리니를 일깨워 삶의 에너지를 흐르게 하여 치유의 힘을 발달시키는 것을 중요하게 여긴다. 인도인들은 이 에너지의 주요한 경로가 척추이며, 그것은 어머니 같은 태초의 대지 에서 깨어나서 하늘까지 나아가며 척추를 따라 흐른다고 한다. 그러므로 뿌리 차크라부터 왕관 차크라까지 이르는 쿤달리니 길은 하늘과 대지의 결합, 즉 '아버지'와 '어머니'의 결합 을 의미한다(Bittlinger, 2010).

신화에서 쿤달리니 길은 샥티와 쉬바의 결합으로 나타난다. 샥티는 여성적인 쿤 달리니 에너지로, 뿌리 차크라에 자신의 센터를 가지며, 거기서부터 솟아오른다. 왕 관 차크라에 자신의 센터를 가지고 있는 쉬바는 뿌리 차크라에서부터 그녀와 동행 하며 각각의 차크라를 채우며 서로 연결하며 통과해 간다. 뿌리 차크라에서도 쉬바 와 샥티는 대지의 에너지와 천상의 에너지의 통합으로 함께 나타난다(Bittlinger, 2010). 우리는 뿌리 차크라로부터 왕관 차크라까지 흐르는 쿤달리니 길에서 가장 높 은 곳에서 가장 낮은 곳까지 연결하며, 온갖 모습으로 나타나는 자기(Self)의 모습을 볼 수 있다. 상황에 따라 자기는 짐승 모습의 상징을 갖기도 한다. 성욕이 억압되거 나 간과되는 곳에서 자기는 남근으로 상징되기도 한다(Jung, 2016).

고대문화에서는 남성의 성기가 뱀으로 상징되었다. 뱀의 머리 형상은 남근의 귀두 (龜頭)를 연상시켰고, 맷돌 형상의 요니-링가는, 남자와 여자의 성스런 결합을 상징했다 (https://ko.wikipedia.org/wiki/\%EB\%A7\%81\%EC\%97\%84). 요니 안으로 들어가는 것은 뱀이며, 생 명의 씨앗이었다. 이집트 상형문자에서는 뱀이 아버지를 나타내며, 신화 속에서 땅의 창조 자, 인류의 수호자, 땅속을 돌고 돌아 대지를 비옥하게 만들어주는 남근으로 등장한다(Jacq, 1997). 남근을 상징하는 뱀은 무의식의 정신적 활력으로, 생산성의 가치를 가지고 있는 종 족 보존의 힘으로 나타난다.

“뱀의 비의(秘儀)중에 신자에게 들어가 수태시키고 영화(靈化)시키면서, 동시에 남 근적 의미를 가지고 있다. 뱀을 숭배하는 배사교도들의 비의에서는 뱀을 대동한 의 
Journal of Symbols \& Sandplay Therapy, Vol.11 No.1.

식이 거행되는데, 이때 뱀들에게 입을 맞춘다. 근대 기독교 종파의 방탕한 광란적 축제에서 이러한 입맞춤은 결코 무시할 수 없는 역할을 한다.”(Jung, 2006, p345) 남 근적 역할은 뱀의 리비도를 의미하고, 뱀과의 접촉은 무의식적 창조적 활력이 연루 될 수 있다. 창조적 정신을 받아들이는 비의인 것이다.

\section{4. 여성적 지혜의 상징으로서의 뱀}

뱀의 무서운 독과 유혹하는 악한 측면의 어두움은 우리를 죽음에 이르게 할 수도 있지만 다른 관점에서는 의식을 깨어나게 하고, 확장시키며, 지혜를 가져다주고, 영혼의 인도자로 여성적 지혜를 가져다주기도 한다. 고대에서 뱀은 땅에 배를 대고 기어 다닌다는 점에서 대지의 대변자이자 생명력으로 대지의 자궁, 임신, 다산, 풍요를 상징했으며, 이런 창조성은 고대 여신의 역할과 동일하였다(Campbell, 2016). 따라서 고대 사회에서 여신은 뱀의 존재와 동일시되어 뱀 여신으로 숭배 받았고, 지혜나 예언과 직접 관련을 맺고 있었다. 그리스 신 화에 나오는 예언자 멜람푸스와 카산드리아는 뱀들이 귀를 핝아 준 후에 예언의 능력을 얻었다(이윤기, 2002). 또한 뱀독에 면역을 얻은 사람들이 우산뱀이나 코브라 등의 독사에 물렸을 때 특정한 뱀독의 화학적 성분으로 인해 거룩한 계시의 경험을 얻기도 했다고 한다(Stone, 2005). 이렇게 독은 누미노제를 지닌 내용들로서 영적 변환의 성격을 지닌다 (Neumann, 2009).

뱀은 계통 발생적으로 온혈 척추동물 체계의 가장 밑바닥에 있는 냉혈 척추동물로, 인간 의 의식이 동물의 정신과 멀리 떨어져 무의식 상태에 있다는 것을 암시한다(Jung, 2016). 이 런 측면은 여성들이 갑자기 돌변해 냉정해지거나 관계를 잔인하게 끊어버릴 때에 냉혈동물 의 본능적 성향이 그녀에게 드러남을 엿볼 수 있다(Jung, 2016). 정신 세계의 반대편에 있는 뱀의 그림자 측면은 인격의 최하 수준의 동물적 충동성이나 본능과 구분되지 않는다. 이것 은 그림자가 그 자체로 사람들에게 인식되기 어려운 것처럼, 뱀도 전적으로 무의식적이어 서 의식이 되기 어려운 것과 비슷하다. 영지주의자들도 뱀을 척수와 골수 등의 반사 기능 과 동일하게 열등한 것으로 여겼다(Jung, 2006). 하지만 뱀은 예수 그리스도를 상징하기도 하며, 지혜와 지고한 영성을 나타내기도 한다. 이렇듯 뱀은 가장 낮은 것이기도 하고, 가장 높은 것이기도 하다. 뱀은 집단 무의식과 본능으로서의 나름의 특이한 지혜를 갖고 있고, 초자연적인 본능이 삶의 지혜를 갖고 있다. 이것이 바로 그 뱀이 지키고 있는 보물이며 동 시에 뱀이 한편으로 악과 어두움을 의미하고, 다른 한편으로 지혜를 의미하는 이유이기도 하다(Jung, 2016).

전통 창세기에서는 아담과 이브가 뱀의 속임수에 빠져 선악과를 먹고 타락했다고 전하지 만, 뱀을 숭배하는 영지주의에서는 “ 그들의 눈이 열렸다.” 고 말한다. 그들의 입장에서는 
이브는 지혜로운 여성으로 천상의 지혜인 소피아(sophia)의 참된 딸인 것이다. 이런 입장에 서는 이브야말로 잠자는 아담을 깨운 존재인 것이다(Stephan, 2006). 영지주의의 한 분파인 오피스파의 생각처럼 아담과 이브는 과일을 훔쳐 먹은 도둑이 아니라, 더 큰 의식을 위해 수동적인 복종의 편안함을 포기한 영웅인 것이다. 우리가 편안함보다 의식에 더 큰 가치를 둔다면 뱀은 유익을 주는 존재인 것이다. 뱀의 유혹, 물림은 편안한 낙원에서 쫓겨나는 고 통을 초래했지만 의식의 확장을 가져왔다(Edinger, 2016).

몽골 지역에 내려오는 카이랍 바위와 관련된 '흰 뱀 이야기' 전설에서도 이런 모습을 볼 수 있다. 흰 뱀은 '용왕의 딸로 위기에 처한 자신을 구해준 고마움으로, 카이랍이란 사냥꾼 을 아버지인 용왕에게 안내한다. 사냥꾼은 흰 뱀의 도움으로 용왕의 입에 있는 보물을 얻 게 되고, 그 날부터 동물의 소리를 들을 수 있게 된다. 어느 날 사냥꾼은 마을에 큰 홍수가 올 것임을 알리는 동물의 소리를 듣는다. 비밀을 애기하면 돌로 변한다는 금기에도 불구하 고, 사냥꾼은 마을을 살리기 위해 동물의 소리를 마을에 알리고, 자신은 바위가 된다는 전 설이다(주채역, 1999). 극동에서 신성한 동물로 여겨지는 흰 뱀은 신성력을 가진 무의식의 지하계적인 여성적 요소로, 사냥꾼을 용왕에게 안내하는 영혼의 인도자로서 기능하고 있다. 흰 뱀은 집단무의식을 관장하는 용왕의 딸로 전체 정신을 연결하게 하는 여성적 지혜를 가 지고 있다.

연금술에서 헤르메스는 지하세계의 전령으로 메르쿠리우스와 동일시되었다. 이들은 바람 같으며, 카오스 안에 사는 지하계적 속성을 갖고 있다. 연금술에서 뱀의 상징은 천치창조의 반복으로 이해되었기 때문에, 연금술사들에게 에덴동산의 뱀은 간교하며 사악한 메르쿠리 우스 신이고, 자신들의 작업과정에 온갖 방해를 하는 악마로 인식되었다(Jung, 2016). 뱀은 훼방, 악마적 성격, 공격 등을 통해 작업 과정들이 발전하게 하는 요소로, 의식화와 문명 의 변화를 추동했다. 뱀은 어두운 지하 세계를 상징하는 동물이기도 하지만 지혜의 상징이 고, 빛과 선, 영적인 동물이기도 하다(Jung, 2016).

\section{5. 재생과 치유의 상징으로서의 뱀}

고대 사람들은 뱀이 허물을 벗으며 자라는 모습에서, 매번 새로 태어나는 능력을 부여받 아 불멸하고 영생하는 존재로 여겼으며, 이로 인해 사람들은 뱀을 신성(神性)한 존재로 인 식하였다(Campbell, 2000). 이런 뱀의 재생의 의미는 그리스 신화에 우로보로스로 등장한다. 우로보로스는 자기 꼬리를 먹는 뱀으로, 스스로를 삼키고 낳고 재생하는 영생의 순환을 반 복하는 원의 형상을 하고 있다. 신비교에서는 우로보로스의 형상이 신성의 바다(Meer der Gottheit)로 등장하는데, 자칫 우로보로스적 근친상간에 해당하는 자아의 해체, 황홀경적 자 아상실을 우려하기도 하나, 그보다는 죽었다가 다시 살아나기(Stirb und Werde)의 재탄생의 
Journal of Symbols \& Sandplay Therapy, Vol.11 No.1.

원리가 드러난 창조적 과정에 있다고 보았다. 우로보로스는 개인적 삶 안에서는 종교적 체 험으로 충만함이 회복되어 우주적 합일에 이르게 될 때 나타나는 상징이기도 하다. 그것은 신화의 시작점이기도 하고, 변용, 깨달음, 완성의 장소로 삶에서 다시 획득한 전체성과 완 전함을 상징하기도 한다(Neumann, 2010).

이집트 사자의 서(The Book of the Dead)에서 태양이 취하는 여정이 12개의 어둠의 시간에 상응하는 12 개의 방으로 나누어진다. 태양선은 처음에 뱀이 거주하는 모래 여울을 지나서 곧 뱀 자체로 변한다. 일곱 번째 시간에 뱀의 형태인 지하세계의 주인을 구체화하는 아포 피스(Apopis)가 나타난다. 이것은 구약성서의 사탄의 선형상이기도 하다. 열한 번째 시간에 태양선의 밧줄은 뱀이 되고, 마침내 열두 번째 시간에 새벽의 방에서 태양선은 뱀을 통하 여 끌어내진다. 그것이 입으로부터 나올 때 떠오르는 태양은 대지모의 가슴 위에 풍뎅이의 형태 속에서 보여 진다. 태양은 다시 하늘로 떠오르기 위해 다시 태어난다(Chevalier et al., 1996). 여기서 뱀은 다시 태양을 재생시키고 다시 태어나게 하는 자를 의미한다. 죽음에서 생명으로, 생명에서 죽음으로의 과정을 이행하게 하는 재생자가 된다.

아트 드 브리스(Ad De Vries)에 의하면, 뱀은 불교에 있어서 생명의 윤회(the wheel of life)를 나타낸다고도 한다. 윤회를 상징하는 뱀은 제 꼬리를 입으로 문 형태로, 이는 우주의 통일, 자연계의 자기충족, 양성구유, 생명의 지속, 육체와 물질의 소멸을 의미한다(한국문화상징사 전편찬위원회, 2006).

이런 모습은 불교 최초 경전인 숫타니파타에서도 나타난다. 시의 형식을 빌어 쓰여진 경 전은 첫 장 '뱀의 비유'란 주제로 17 개 단락이 '이 세상도 저 세상도 다 버린다. 뱀이 묵은 허물을 벗어버리듯' (법정, 2005)이란 문구를 반복하며 이어진다. 이 시에서는 이 몸이 나고 사라짐은 뱀이 허물을 벗음과 같고, 사람이 옛집을 빠져 나오는 것과 같으니 옥심과 집착 에 매여 있는 게 덧없다고 이야기한다. 이런 뱀의 재생의 의미는 몸과 마음의 자유로운 해 방, 알아차림이 해탈이라고 할 수 있다.

뱀의 재생과 불사의 의미는 제주도 서사무가(敍事巫歌)인 차사 본풀이에도 등장한다. 마 침 담 구멍에 있던 뱀이 저승차사인 까마귀인 적패지(赤牌旨)를 받아 삼키고 들어가 버렸 다. 그래서 뱀은 죽는 법이 없이 아홉 번 죽었다가도 열 번 다시 살아난다고 한다(한국문화 상징사전편찬위원회, 2006).

뱀의 이런 삶과 죽음이라는 양면적인 의미는 뱀의 독에서도 볼 수 있다. 독뱀에 물렸을 경우 바로 치료하지 않으면 몸에 독이 퍼져 죽음에 이를 수도 있다. 그러나 이 독을 몇 배 로 희석해서 사용한다면, 사람의 생명을 구하는 치료제가 된다. 이렇듯 뱀의 독은 사람을 죽이기도 하고, 치유하기도 한다. 히포크라테스의 말처럼 '같은 것이 같은 것을 치료한다. 뱀의 치유에 대한 대표적 상징에는 현재 세계보건기구(WHO: World Health Organization)의 앰 블럼 마크로 사용되고 있는 '아스클레피오스(Asclepius)의 지팡이' 가 있다(https://namu.wiki/w/ 
\%ЕC\%95\%84\%ЕC\%8A\%A4\%ED\%81\%B4\%EB\%A0\%88\%ED\%94\%BC\%EC\%98\%A4\%EC\%8A\%A4). 아스클레피오스는 아폴론의 아들로, 태어날 때부터 죽음으로부터 삶으로 인도된 인물이다. 그의 어머니 코로니스는 임신 중 외도로 화형을 받게 되었는데, 아스클레피오스는 화장용 장작더미에 있는 동안 자궁에서 꺼내져 구사일생으로 살게 되었다. 죽음으로부터 탄생한 치유의 힘은 '상처받은 원형' 에 속한다. 케레니에 의하면 이 신화는 심리학적으로 '고통이 어둠속에서 편안함을 느끼고 거기서 빛의 씨앗과 회복을 발견하는 역량과 그러한 역량을 가진 태양 같은 치유자 아스클레피오스를 마술같이 낳은 것“ 이라고 하였다(Edinger, 2015). 아스클레피오스는 인간을 불멸의 존재로 만들 수 있는 비법을 가진 의술, 치유의 신으로 (Campbell, 2016), 한 마리 뱀이 감겨 있는 지팡이를 가지고 다녔다. 그는 아테네의 도움으로 메두사의 피를 얻어 메두사의 왼쪽에서 나오는 피로는 생명을 죽이고, 오른쪽에서 나오는 피로는 치료를 하여 생명을 회복시켰다(Campbell, 2000). 뱀의 피로 사람을 죽이기도 살리기 도 한 것이다.

지하세계 초월의 상징, 서양에서 의술의 상징으로 널리 알려져 있는 것은 두 마리 뱀이 얽혀 있는 헤르메스 지팡이Caduceus인데, 융은 이 길들여진 뱀과 길들이지 않은 뱀이 겨루는 지팡이 모습에서 질환 치료의 원리를 읽었다(한국문화상징사전편찬위원회, 2006). 또한 헤르 메스 지팡이는 시간의 영역에서 죽음, 과거를 내던지고 미래로 움직이는 생명의 힘을 상징 하기도 한다(Campbell, 2016). 언뜻 보면, 헤르메스 지팡이는 아스클레피오스의 지팡이와 비 슷해 보이기도 하는데, 헤르메스 지팡이는 죽은 사람을 저승으로 데려가는 것이고, 아스클 레피오스의 지팡이는 죽어가는 사람 즉 저승으로 내려가는 사람을 다시 이승으로 데려오는 다른 용도로 쓰였다고 한다(https://namu.wiki/w/\%EC\%95\%84\%EC\%8A\%A4\%ED\%81\%B $4 \% \mathrm{~EB} \%$ $\mathrm{A} 0 \% 88 \% \mathrm{ED} \% 94 \% \mathrm{BC} \% \mathrm{EC} \% 98 \% \mathrm{~A} 4 \% \mathrm{EC} \% 8 \mathrm{~A} \% \mathrm{~A} 4)$. 이는 뱀이 겨울동안 땅속이나 깊은 굴에서 보내다가 봄이 되면 지상의 세계에서 모습을 볼 수 있는 것과 유사하다.

아스클레피오스 신전에서는 현대의 정신치료와 비슷하게 꿈이 병을 치료한다고 믿었다. 이 신전에 와서 목욕을 하고 신전 옆 성스러운 수면실 아바톤(Abaton)으로 들어가서 밤을 보내면 그동안 치유가 일어날 것이라고 여겼다. 수면 중 꿈속에서 뱀이 상처를 물면 치유 가 되거나 신이 나타나 치료 방법을 알려 준다고 믿었다(이부영, 2005). 이 신전 안에서의 경험은 우리 자신 안에 있는 치유 능력을 일깨우는 것이고, 정신에 의한 치유 능력을 불러 내어, 그의 몸 안에서 분출되는 뱀의 능력을 꿈꾸는 동시에 신이 그를 치료하는 꿈을 꾼 것이다(Campbell, 2016).

구약성서 민수기에서도 뱀이 치유의 상징으로 사용되었다. 모세는 이스라엘 백성들과 가 나안 땅으로 가기 위해 광야에서 생활을 한다. 이스라엘 백성들은 에굽을 탈출한 기쁨도 잠시고, 광야에서 어려움을 겪자 그 전의 노예 생활을 그리워하며 하나님을 원망한다. 하나 님은 그런 그들을 벌하기 위해 불 뱀을 보내 물게 한다. 하지만 모세가 그들의 죄를 용서 
Journal of Symbols \& Sandplay Therapy, Vol.11 No.1.

해 줄 것을 구하고, 하나님은 모세에게 만든 구리 뱀을 장대 끝에 들게 하여 구리 뱀을 본 자는 살게 하였다. 여기서도 뱀의 양면적 모습을 볼 수 있는데, 불 뱀은 하나님을 저주한 이스라엘인들에 대한 하나님의 심판이고, 구리 뱀은 이스라엘 백성들의 회개로 하나님이 그들을 치유하려는 목적에서 준 치료제인 것이다(Walton외, 2001). 신약성서에서는 이런 구 리 뱀처럼 그리스도는 십자가에 올려지는 구원자의 상으로 표상되기도 한다. 뱀의 상(像)은 독을 주입하여 죽이고 병들게 하는 요소를 대변하기도 하지만 치유와 회복을 불러오는 본 능상임을 알 수 있다.

\section{6. 내담자의 꿈과 모래상자에 나타난 뱀}

\section{1) 사례 1 : 꿈에 나타난 뱀의 상징적 의미}

40 대 초반의 여성 지나(가명)씨는 20년 가까이 다니던 직장을 그만 두고, 우울하고 무기 력하여 상담을 받게 된 내담자이다. 지나씨는 외형적인 성격으로 사회생활에 적응을 잘 하 고, 자신의 일도 성실히 책임을 다하며 바쁘게 지냈지만 어느 순간부터 웃음이 줄어들고, 매일 반복되는 일상에 지치고, 우울함이 더해져 죽고 싶다는 생각이 들어서 살고자 직장을 정리했다고 한다. 상담이 진행되던 중 지나 씨는 뱀이 몸을 기어 다니는 느낌이 생생하게 기억에 남는 인상적인 꿈을 보고하였다. 뱀의 [꿈1]은 다음과 같다.

[꿈 1]

나는 깊은 산 속에 있는 것 같다. 무슨 게임 코스 같은데 한 코스를 마치면 다른 코스가 나타난다. 나는 비슷한 또래의 낮선 여자 친구와 함께 쫓기고 있고, 원주민 남자(인디언과 비슷한) 2 명이 우리를 잡기 위해 쫓아오고 있다. 또 다른 무리의 사 냥꾼처럼 보이는 사람들이 총을 들고 원주민들을 잡으려 한다. 도망가다 숨기 좋은 장소를 찾았다. 돌로 만들어진 무덤이다. 건물이 십자 모양으로 생겨서 벽 뒤에 숨 으려 하다가 너무 찾기 쉬울 것 같아 다른 장소를 찾는다. 땅 밑으로 들어가 문을 열고 동그랗게 생긴 방에 들어가 숨는다. 숨을 돌리고 있는데, 우리를 잡으려 했던 원주민 2 명도 숨으러 이곳에 온 것 같다. 그들이 문을 열고 들어와 눈이 마주치는 순간 난 숨이 멎을 것 같았다. 그들은 눈을 반짝이며 자신들이 손에 쥐고 있던 뱀 주머니를 우리에게 풀었다. 내 몸에 뱀이 스물 스물 기어 다니는데 나는 눈을 감고 기도를 한다.'살고 죽는 게 주님께 달렸으니 알아서 하시라고 '나는 친구 손을 꼭 잡고 있다. 담담히 버텼는데 시간이 지나면서 뱀이 꾸물거리는 것을 참기가 힘들었 다. 그래서 단호한 목소리로 그들에게‘뱀을 치우라’고 애기했다. 내 말투가 어땠는 지 그들은 내가 무서워하지 않는 것 같다며 뱀을 치운다. 마치 무슨 시험을 통과한 느낌이 들었다. 우리를 구하려는 이들의 소리가 들리는 것 같다. 작은 뱀 한 마리가 
가슴 옆을 무는 것 같아 나는 뱀의 머리를 잡아 바닥에 던지는데 입에 하얀 걸 물 고 있었다. 나는 뱀이 속옷을 물었나보다 생각하고, 거기를 빠져 나온다. 밖에서 네 모난 돌문(알지 못하는 글씨가 쓰여 있음)을 바라보는데, 돌문 밖으로 나와 있던 검 은 띠가 뱀이 끌어당기는 듯 문 안으로 들어가는 모습이 보였다.

이 꿈 속에서 코스 게임을 하는 것은 꿈꾼 이가 어떤 이행과정에 있음을 시사한다. 인디 언 같은 원주민 남성 2 명은 아직 개발되지 않은 원시적인 미분화된 남성적 요소이고, 총을 든 한 무리의 남성들은 목표 지향적이고, 문명화된 요소로 꿈꾼 이에게 외부 세계와 목표 지향적인 태도로 활성화하며 살게 한 무의식적 남성적 요소일 것이다(Boa, 2004). 남성들로 부터 쫓기면서 들어가는 십자가 표상의 무덤은 입문식이나 죽음으로 내려가는 변환의 장소 로 이해할 수 있다(Jung, 2004). 이런 공간에서 원시적인 남성상은 뱀을 풀어 놓는다. 여기 등장하는 뱀은 꿈 자아의 몸을 기어 다니며 꼼짝 못하게 한다. 여기서 뱀은 본능적 활력을 자극하는 상임과 동시에 그곳에서 멈추어서 우울함과 죽음의 과정을 견디도록 하는 여성적 지혜를 자극하는 상일 수 있다. 그 고통스러운 시간을 견뎌내니, 꿈의 자아는 시험에 통과 한 느낌이 든다. 일어나려고 하는데 작은 뱀 한 마리가 가슴을 물고 있는 걸 발견한다. 뱀 이 여성의 가슴 쪽의 속옷을 문다는 것은 여성적 기초에 대한 새로운 통찰을 각성하는 것 으로 고려할 수 있겠다(Edinger, 2016). 이 꿈에서 뱀은 무기력하고 우울감에 시달리던 꿈꾼 이에게 신체를 각성시키면서 몸의 활력을 인식시킴과 동시에 새로운 가슴 부위에 속옷을 물음으로써 뱀이 가진 여성적 지혜, 의식화를 촉발시키고 있다. 이 꿈의 뱀은 여성적 지혜 와 여성적 기초인 에로스 원리를 각성시키며, 새로운 의식의 전환을 추동하는 것으로 보인 다. 여성적 원리의 근간은 삶을 수용하고, 관계 맺고, 자연 또는 무의식과 조화를 이루어 감을 의미할 것이다. 오랜 직장 생활과 육아라는 바쁜 생활을 접은 후에도 편안히 쉬며, 여 성으로서의 삶을 받아들이지 못하는 지나 씨에게 이 뱀의 꿈은 여성적 지혜와 여성적 기초 가 무엇인지를 일깨움으로써 새로운 의식의 변화를 촉발시킨 것으로 보인다.

\section{2) 사례 2 : 모래 놀이 그림에 나타난 뱀의 상징}

민우(가명)는 10 대 초반 소년으로 사회의 규칙과 규율을 중요시하는 엄격한 부모님의 간 섭과 훈계, 계속되는 학교에서의 친구들과의 관계 문제로, 자존감이 많이 떨어져 있고 무기 력하고 우울한 상태였다. 민우는 학교 가기 싫다고 호소를 하여 담임 선생님의 권유로 상 담을 받게 되었다. 민우는 모래놀이 첫 시간에 상자에 등장한 큰 뱀을 가지고는 자신의 목 에 둘러보기도 하고, 신기한 듯 흔들어 보기도 하고, 바닥을 기어 다니게 하는 모습을 보였 다. 그러고는 상담자 쪽으로 뱀을 가져와 상담자에게 던지는 시늉을 하며 위협하는 행동도 보였다. 큰 뱀을 상자 중앙 상단에 놓고는, 작은 뱀들을 한아름 안고와 상자 좌측 하단에 
Journal of Symbols \& Sandplay Therapy, Vol.11 No.1.

배치하면서 뱀들의 세상이라고 한다. 민우는 놀이하듯이 피겨를 만지며 이야기를 진행하였 는데, 뱀이 원을 만들어 군인들을 다 죽였다고 한다. 뱀과 악어의 세상이 되었는데 둘이 싸 우다 악어가 뱀의 목을 물기도 한다. 동물에게 노예 취급 받지 않는다며, 다시 한 아름 사 람들을 안고와 우측 하단에 배치하며 도끼를 가져와 악어 입에 물리기도 하고, 도끼 든 사 람이 뱀의 마디를 자르려 하고, 해적들이 몰려온다고 한다. 악어, 뱀이 죽는구나 하며, 갑 옷 입은 사람들이 다 이겼다고 한다. 다음은 민우가 작업한 모래그림이다.

[모래그림1]

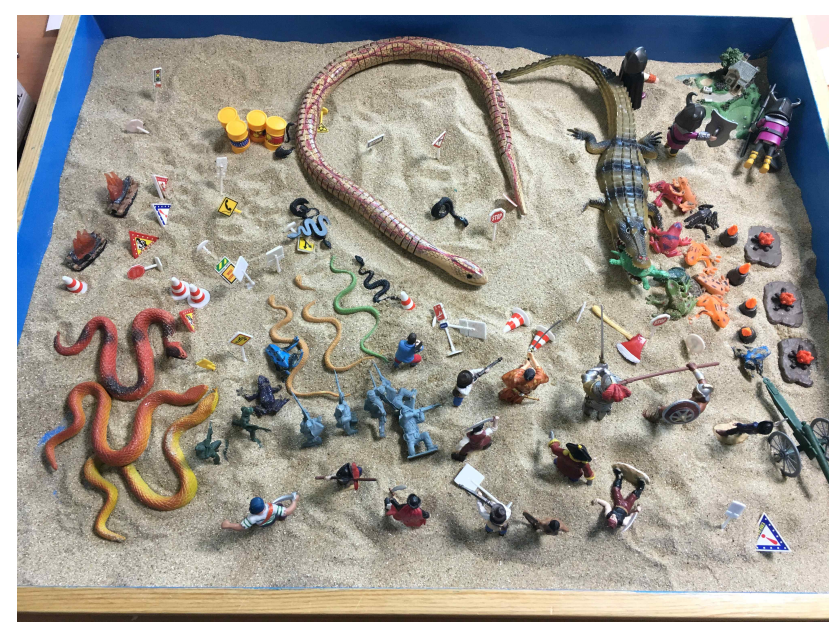

민우는 상자 중앙에 있는 뱀을 만지고 놀며, 상담자에게 던지는 시늉을 하였다. 이런 행 동은 민우가 뱀을 무서워하지 않고, 뱀과 친숙한 측면일 수 있겠으나 뱀의 본능이 무의식 적으로 영향을 주고 있는 것임을 짐작할 수 있다. 모래상자에 등장한 뱀은 인간성에서 멀 리 떨어져 있는 무의식적 지하계적인 본능상임을 이해할 수 있는데, 상당히 많은 뱀들은 이런 뱀의 본능이 활성화되어 있고, 지배적인 특성을 나타내는 것으로 보인다. 뱀은 악어와 함께 다른 동물들도 삼킬 정도로 위협적인 특성을 보인다. 냉혈 동물들이 활성화는 민우가 본능적인 힘에 지배당하고 있는 경향을 드러내며, 현실에서 민우가 지닌 흥분성, 충동성, 공격적인 성향으로 고려할 수 있다.

실제로 민우는 초등학교 1학년 때 $\mathrm{ADHD}$ 진단을 받고 약을 먹기도 하였고, '친구들이 놀 이에 끼워주지 않으면 친구들을 때리거나 공을 빼앗는 모습을 보였다, 고 어머니가 보고 하였다. 민우의 어머니는 민우가 학교에서 문제가 생길 때마다 학교를 옮기거나 이사를 하 며 문제를 해결하려 하셨고, 민우와 친구의 문제를 어른들의 문제로 크게 만들어 민우가 설 자리를 잃게 하고 있었다. 민우는 부정적 모성원형의 지배력으로 의식이 분화되지 못하 
고 있고, 성장의 어려움을 겪고 있는 것으로 보인다. 하지만 민우는 모래상자에서 보듯이 총을 든 남자들이 뱀을 겨누고 있기도 하고, 도끼를 든 사람이 큰 뱀을 자르는 모습을 보 이기도 하며, 집어삼키는 무의식적 본능인 뱀을 물리치며 대응하려고 애를 쓰고 있는 것으 로 보인다. 이런 남성원리들이 민우에게 점차 일어나고 있는 분화의 내용을 시사한다고 볼 수 있다. 이 모래 놀이 그림에서 무의식적 본능적 경향으로부터 분화되고, 분리하려는 내용 이 시도되고 있고, 발현되고 있음을 짐작할 수 있다.

\section{III. 결 론}

신화와 종교, 인간의 마음에서 뱀은 실로 지대한 의미를 지님을 살펴보았다. 뱀의 집어삼 키는 특성은 의식으로부터의 해방이 힘겨울 때, 의식의 분화와 발전을 가로막는 무의식적 인 상으로 개체 발전을 저해하고, 무의식에 고착시키려는 파괴적인 측면으로 나타난다. 뱀 의 유혹이나 물림(공격)은 그 자체로 고통스러운 상황이지만 의식의 통찰과 확장을 가져오 고, 대지와 현실에 뿌리박은 삶을 실어 나르는 계기를 마련한다. 뱀은 무의식의 지하계적인 요소로, 의식에서 배제된 무의식적 요소, 전체정신을 연결하게 하는 여성적 지혜를 가지고 있다. 또한, 생명의 씨앗인 남근을 상징하는 뱀은 무의식적 정신적 활력으로 리비도를 의미 하고, 이런 뱀과의 접촉은 무의식적 창조적 활력을 보상하며 다시 생명력을 복원하기도 한 다. 뱀은 치유의 원형으로 죽음에서 생명으로, 생명에서 죽음으로의 과정을 이행하는 재생 자이고, 치유와 회복을 상징한다. 이런 뱀은 어두운 지하계적이며, 피괴적인 요소를 지니고 있지만 뱀의 지혜는 창조적 요소이기도 한다. 이시스가 뱀을 풀어 독을 주지만 독을 치료 하는 치료자이듯 뱀은 독이자 치료제이다. 이런 뱀은 역설적 본성을 지닌 전체성의 상이라 할 수 있다.

꿈 사례에서의 뱀은 본능으로부터 지나치게 분리되어 있는 여성 내담자에게 정신적 활력 과 갱생의 에너지를 보상하며 의식화를 촉발시키기 위해 등장한다. 지나씨의 꿈에 등장한 뱀은 몸을 스물스물 기어 다니는 징그러운 느낌을 남겼지만, 뱀과의 접촉은 잠자던 신체적 감각을 깨우고 있다. 뱀과의 접촉은 무의식의 창조적 활력의 정신 에너지를 일깨우고 있다.

모래 그림에서 뱀은 집어삼키는 무의식적 측면으로 이런 내용이 지배적으로 활성화될 때 아동은 의식의 분화와 발전에 어려움을 겪게 되고, 때로는 병리적 특성으로도 드러날 수 있다. 그러나 아동에게 뱀의 측면을 대면하고, 극복하게 할 수 있는 용기를 줌으로써 새로 운 의식의 발전을 가능케 할 수 있다.

무의식의 배정을 통하여 나타나는 뱀의 상징에 대한 고찰은 무의식의 어떤 의도와 강력 한 처방이 담겨 있는지를 탐색하는데 도움을 주었다. 뱀의 출현은 변환을 위한 무의식의 
Journal of Symbols \& Sandplay Therapy, Vol.11 No.1.

시급한 요청으로 고려할 수 있는 것이다. 본 연구에서 뱀의 고찰은 임상에서 연구자에게 내담자의 모래상자나 꿈을 이해하는데 많은 도움을 주었고, 귀한 통찰을 제공하였고, 의문 에 쌓인 물음표에 작은 해답을 주었다. 그렇다고 이 뱀의 고찰이 전체 뱀의 의미를 낱낱이 밝히지는 못할 것이다. 그렇게 하는 것은 불가능하다. 그러나 적어도 뱀의 특성을 전반적으 로 살펴보고자 하는 치료자들에게 작은 안내가 될 것으로 기대한다.

뱀은 인간이 외면하고, 억압하며, 소외시키는 영역에 존재하는 무의식의 상으로, 우리의 전체성에 균형을 맞추기 위해 등장하여 우리를 구불구불한 개성화 과정으로 인도해 가는 상징일 것이다. 뱀은 독으로 사람을 살리기도 하고, 죽이기도 하며, 치유와 회복을 불러오 는 전체성을 담고 있는 상징이다. 그렇기에 뱀은 가장 낮은 곳에서부터 가장 높은 곳까지 연결하는 자기(Self)의 모습을 드러내는 상일 것이다. 자기(Self)는 상징을 통해서 스스로의 참 모습을 나타내고, 성장해 가며,(소병혜, 2018) 전체성에 다가가도록 “우리의 운명을 신비스 럽게 안내하는 정신"(Jung, 2016)인 것이다.

\section{참고문헌}

법정 (2005). 숫타니파타. 파주: 이레.

심재한, 김종범, 민미숙, 오홍식, 박병상 (2007). 양서파충류도감. 파주: 보리.

소병혜 (2018). 개성화를 위한 영적 안내의 상징으로서의 지팡이. 상징과 모래놀이치료, 9(2), 43-59.

이부영 (2005). 분석심리학. 서울: 일조각.

이윤기 (2002). 길 위에서 듣는 그리스 로마신화. 서울: 작가정신.

주채역 (1999). 몽골구비설화. 서울: 백산 자료원.

한국문화상징사전편찬위원회 (2006). 한국문화상징사진1. 서울: 두산동아.

한국 브리태니커 (1993). 브리태니커 세계대백과사전. 서울: 웅진출판.

Bittlinger, A. (2010). 칼융과 차크라 (Carl G. Jung and Chakras) (최여원 역). 창원: 슈리 크리슈 나다스 아쉬람.

Campbell, J. (2013/2016). 여신들 (Goddesses) (구학서 역). 파주: 청아출판사.

Campbell, J. (1968/2000). 신의 가면III: 서양신화 (The Masks of God Vol. III: Occidental Mythology) (정영목 역). 서울: 까치글방.

Chevalier, J. \& Gheerbrant, A. (1996). The penguin dictionary of symbols. Penguin Books, London. Jacq, C. (1997). 이집트상형문자이야기 (김진경 옮김). 서울: 예문.

Edinger, E. (2015). 연금술의 상징과 심리치료 (Alchemical Symbolism in Psychotherapy) (김진숙 번 
역). 서울: 돈화문출판사.

Edinger, E. (1972/2016). 자아발달과 원형 (Ego and Archetype) (장미경 역). 서울: 학지사.

Boa, F. (1988/2004). 융학파의 꿈해석 (The way of the dream) (박현순, 이창인 역). 서울: 학지 사.

Jung C. G. (1989). Mysterium Coniunctionis, C.W.14, par178.

Jung C. G. (1984/2002). 융 기본저작집2 원형과 무의식 (Grundwerk C. G. Jung Bd.2 Archetyp und UnbewuKtes) (한국융연구원 C.G. 융 저작번역위원회 역). 서울: 솔 출판사.

Jung C. G. (1985/2006). 융 기본저작집8 영웅과 어머니원형 (Grundwerk C. G. Jung Bd. 8 Heros und Mutterarchetyp) (한국융연구원 C.G. 융저작번역위원회 역). 서울: 솔 출판사.

Jung C. G. (2016). 아이온 (AION) (김세영, 정명진 역). 서울: 부글북스.

Jung C. G. (2018). 환상해석 (Interpretation of visions) (정명진 역). 서울: 부글북스.

Kerenyi, K. (1997/2002). 그리스신화 I 신들의 시대(Die Mythologie der Griechen) (장영란, 강훈 역). 서울: 궁리출판.

Moon, B. (1997). An encyclopedia of archetypal symbolism, (Vol.1). Boston: Shambala, 139-140.

Neumann, E. (2010). 의식의 기원사 (Ursprungsgeschichte des Bewusstseins) (이유경 역). 서울: 분 석심리학연구소.

Neumann, E. (2009). 위대한 어머니 여신 (The Great Mother). 파주: 살림출판사.

Stephan, A. (2006). 이것이 영지주의다 (Gnosticism) (이재길 역). 서울: 샨티.

Stone, M. (2005). 하나님이 여자였던 시절 (When God was a woman) (정영목 역). 서울: 뿌리 와 이파리.

Turner, B. A. (2009). 모래놀이치료 핸드북 (The handbook of sandplay therapy) (김태련외 역). 서 울: 학지사.

von Franz, M. L. (2017/2002). 영원한 소년과 창조성 (Puer aeternus. seoul) (홍숙기 역). 서울: 한 국융연구원.

von Franz, M. L. (1980). Alchemy. Toronto: Inner City Book.

von Franz, M. L. (1999). Archetypal Dimensions of the psyche. Boston: Shoambhala.

Walton, J. H., Mattthews. V. H., \& Chavalas, M. W. (2001). IVP 성경배경주석 구약 (The IVP Bible Background Commentary) (정옥배 역).

인터넷 검색

뱀-나무위키[웹사이트].(2019.9.20.). URL:https://namu.wiki/w/\%EB\%B1\%80

스핑크스-나무위키[웹사이트].(2019.9.20.). URL:

https://terms.naver.com/entry.nhn?docId $=1642031 \&$ cid $=60656$ \&categoryId $=60656$ 
Journal of Symbols \& Sandplay Therapy, Vol.11 No.1.

히드라-나무위키[웹사이트].(2019.9.20.). URL:

https://namu.wiki/w/\%ED\%9E\%88\%EB\%93\%9C\%EB\%9D\%BC

아스클레피오스-나무위키[웹사이트].(2019.9.20.). URL:

https://namu.wiki/w/\%EC\%95\%84\%EC\%8A\%A4\%ED\%81\%B4\%EB\%A0\%88\%ED\%94\%BC\%EC\% 98\%A4\%EC\%8A\%A4

요니와 링가-위키백과[웹사이트].(2019.9.20.). URL:

https://ko.wikipedia.org/wiki/\%EB\%A7\%81\%EC\%97\%84

투고일 : 2020. 03. 30

수정일 : 2020. 05. 09

게재확정일 : 2020. 05. 13 